Supporting Information

\title{
Enhanced Gearing Fidelity Achieved Through Macrocyclization of a Solvated Molecular Spur Gear
}

Marcus J. Jellen ${ }^{\ddagger}$, Ieva Liepuoniute ${ }^{\ddagger}$, Mingoo Jin, Christopher G. Jones, Song
Yang, Xing Jiang, Hosea M. Nelson*, K. N. Houk* , Miguel A. Garcia-Garibay* 


\section{Table of Contents}

Section A. General Information $\quad$ S3

Section B. Synthesis and Characterization $\quad$ S3

1) Synthesis and characterization of monoprotected triptycene 11a $\quad$ S3

2) Synthesis and characterization of fully protected gear 14a $\quad$ S6

3) Synthesis and characterization of macrocyclic template 8a $\quad$ S9

4) Synthesis and characterization of 2,7-(bis-diphenylphosphino)-napthalene $9 \quad$ S12

5) Synthesis and characterization of molecular spur gear 10a $\quad$ S15

6) Synthesis and characterization of monoprotected triptycene 11b $\quad$ S17

7) Synthesis and characterization of fully protected gear 14b $\quad$ S20

8) Synthesis and characterization of macrocyclic template $\mathbf{8 b} \quad \mathbf{S 2 3}$

9) Synthesis and characterization of molecular spur gear 10b $\quad$ S26

$\begin{array}{ll}\text { Section C. Variable Temperature }{ }^{1} \text { H NMR } & \text { S28 }\end{array}$

$\begin{array}{ll}\text { Section D. Electron Diffraction } & \text { S28 }\end{array}$

$\begin{array}{ll}\text { Section E. Computational Methods } & \text { S30 }\end{array}$

Section F. References $\quad$ S33 


\section{Section A. General Information}

Unless otherwise notified all commercially available compounds were used as received without further purification. 9,10-diethynyl triptycene, 11a, 9,10-diethynyl triptycene- $d_{8}, \mathbf{1 1 b}$, and naphthalene-2,7-ditriflyl, S1 were prepared as reported in the literature. ${ }^{1,2}$ Thin-layer chromatography (TLC) plates pre-coated with silica gel 60 F254 were purchased and were visualized using a UV lamp. Flash column chromatography was performed using silica gel (230-400 mesh) as the stationary phase. Anhydrous tetrahydrofuran (THF) was distilled from sodium-benzophenone in a continuous still under an atmosphere of argon. Melting points of solids were measured without calibration of the apparatus. ${ }^{1} \mathrm{H}$ NMR and ${ }^{13} \mathrm{C}$ NMR spectra in solution were recorded at $500 \mathrm{MHz}$ and $126 \mathrm{MHz}$, respectively. Chemical shifts are reported in ppm and the (residual) solvent signals of $\mathrm{CDCl}_{3}\left({ }^{1} \mathrm{H}\right.$ NMR: $\delta 7.26 \mathrm{ppm} ;{ }^{13} \mathrm{C}$ NMR: $\left.\delta 77.0 \mathrm{ppm}\right)$ or $\mathrm{CD}_{2} \mathrm{Cl}_{2}$ ( ${ }^{1} \mathrm{H}$ NMR: $\delta 5.32 \mathrm{ppm} ;{ }^{13} \mathrm{C}$ NMR: $\left.\delta 53.8 \mathrm{ppm}\right)$ were used as reference. Multiplicities of the peaks are reported as singlet (s), doublet (d), triplet (t), or multiplet (m). The coupling constants $\mathrm{J}$ are reported in $\mathrm{Hz}$. Infrared spectra (IR) were recorded with a HATR-FTIR instrument. High-resolution mass spectra were acquired using APCI/MALDI ionization methods and the signal was detected with a TOF detector.

\section{Section B. Synthesis and Characterization}

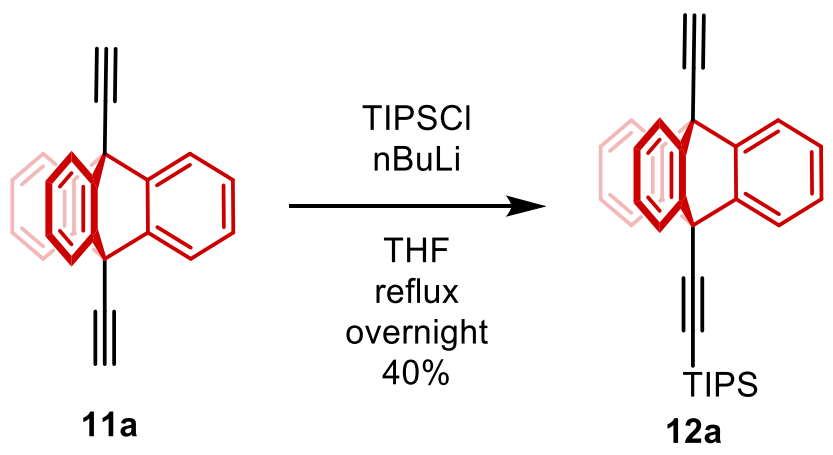

A $50 \mathrm{~mL}$ round bottom flask was charged with dialkyne 11a $(300 \mathrm{mg}, 0.99 \mathrm{mmol})$ and placed under an inert argon atmosphere. $15 \mathrm{~mL}$ of THF were then added and the solution was cooled to $-78{ }^{\circ} \mathrm{C}$. n-butyllithium $(0.6 \mathrm{~mL}, 0.99 \mathrm{mmol})$ was then added to the flask and the mixture was stirred for 30 minutes. Triisopropylsilyl chloride $(0.24 \mathrm{~mL}, 1.14 \mathrm{mmol})$ was then added to the flask and the reaction mixture was first warmed to room temperature and then brought to reflux overnight. The mixture was then cooled to room temperature and quenched with saturated ammonium chloride solution. The resultant solution was extracted three times with DCM (10 $\mathrm{mL}$ ), dried over $\mathrm{MgSO}_{4}$, and concentrated to yield a white powder. Purification of the crude mixture was accomplished by flash chromatography ( $\mathrm{SiO}_{2}$, Hexanes) to yield $200 \mathrm{mg}$ of pure monoprotected product (44\% yield) as a white solid. Diprotected and unprotected products were combined, deprotected with tetrabutylammonium fluoride and purified with a hexane column to be reused in subsequent reactions.

Rf $0.37\left(\mathrm{SiO}_{2}\right.$, Hexane);

'H NMR (500 MHz, $\left.\mathrm{CDCl}_{3}\right) \delta 7.83-7.79(\mathrm{~m}, 3 \mathrm{H}), 7.79-7.74(\mathrm{~m}, 3 \mathrm{H}), 7.20-7.07$ (m, 6H), $3.31(\mathrm{~s}, 1 \mathrm{H}), 1.43-1.26(\mathrm{~m}, 21 \mathrm{H})$; 
${ }^{1} \mathrm{C}$ NMR $\left(126 \mathrm{MHz}, \mathrm{CDCl}_{3}\right) \delta 143.56,143.20,125.97,125.87,122.53,122.23,101.25,94.28$, 81.04, 78.27, 53.51, 52.34, 19.02, 11.59;

IR (Film) 3285.72, 2943.08, 2865.07, 2175.53, 1453.33, 1302.91, 1219.17, 1032.29, 881.61, $751.82,745,696.4,674.13,657.22,639.94,489.35 \mathrm{~cm}^{-1}$;

HRMS (APCI) Calcd for $\mathrm{C}_{33} \mathrm{H}_{34} \mathrm{Si}(\mathrm{M}+1)$ 458.24298, found 459.24859.

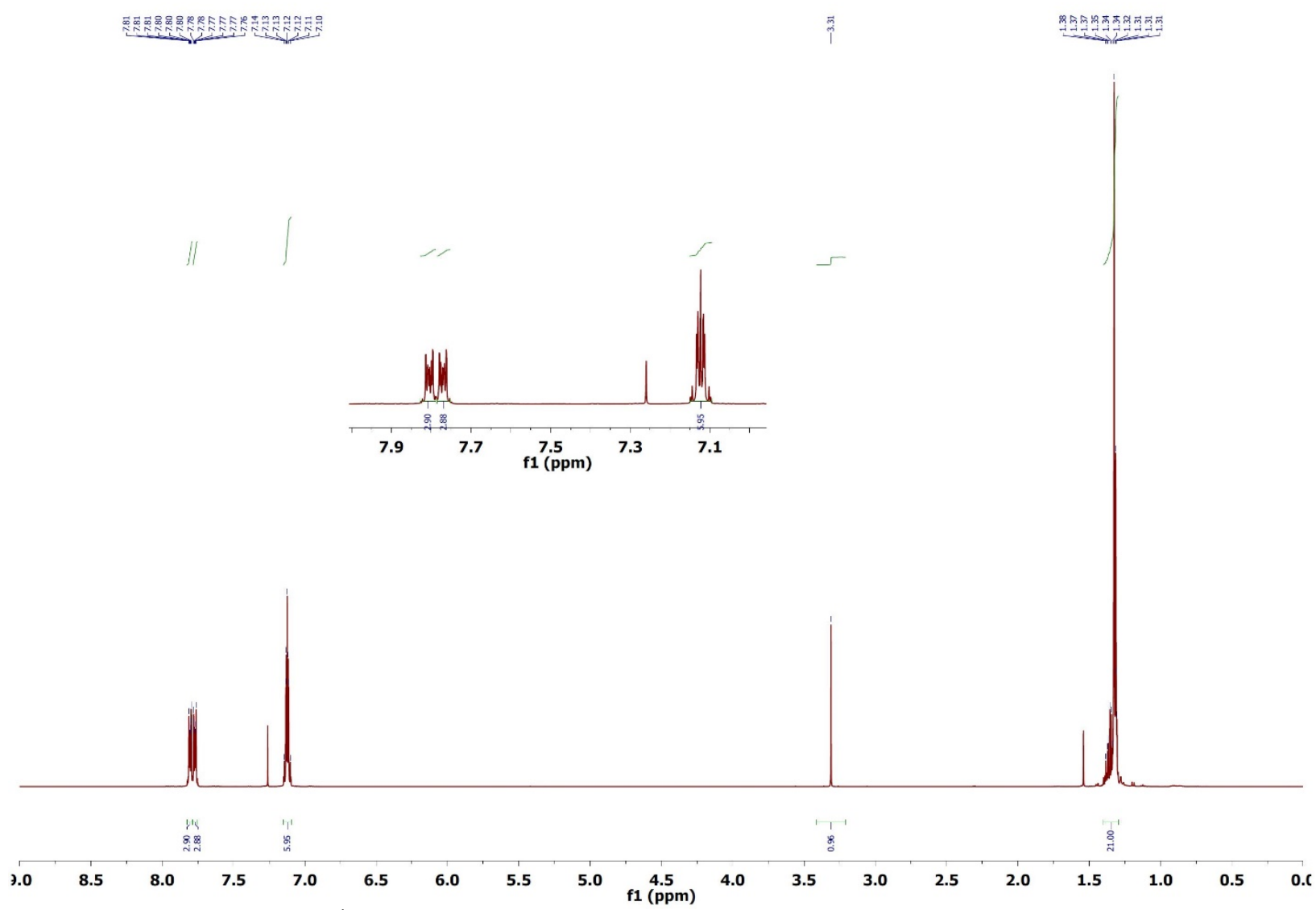

Figure S1. ${ }^{1} \mathrm{H}$ NMR spectrum of compound 12a at $500 \mathrm{MHz}$ in $\mathrm{CDCl}_{3}$. 


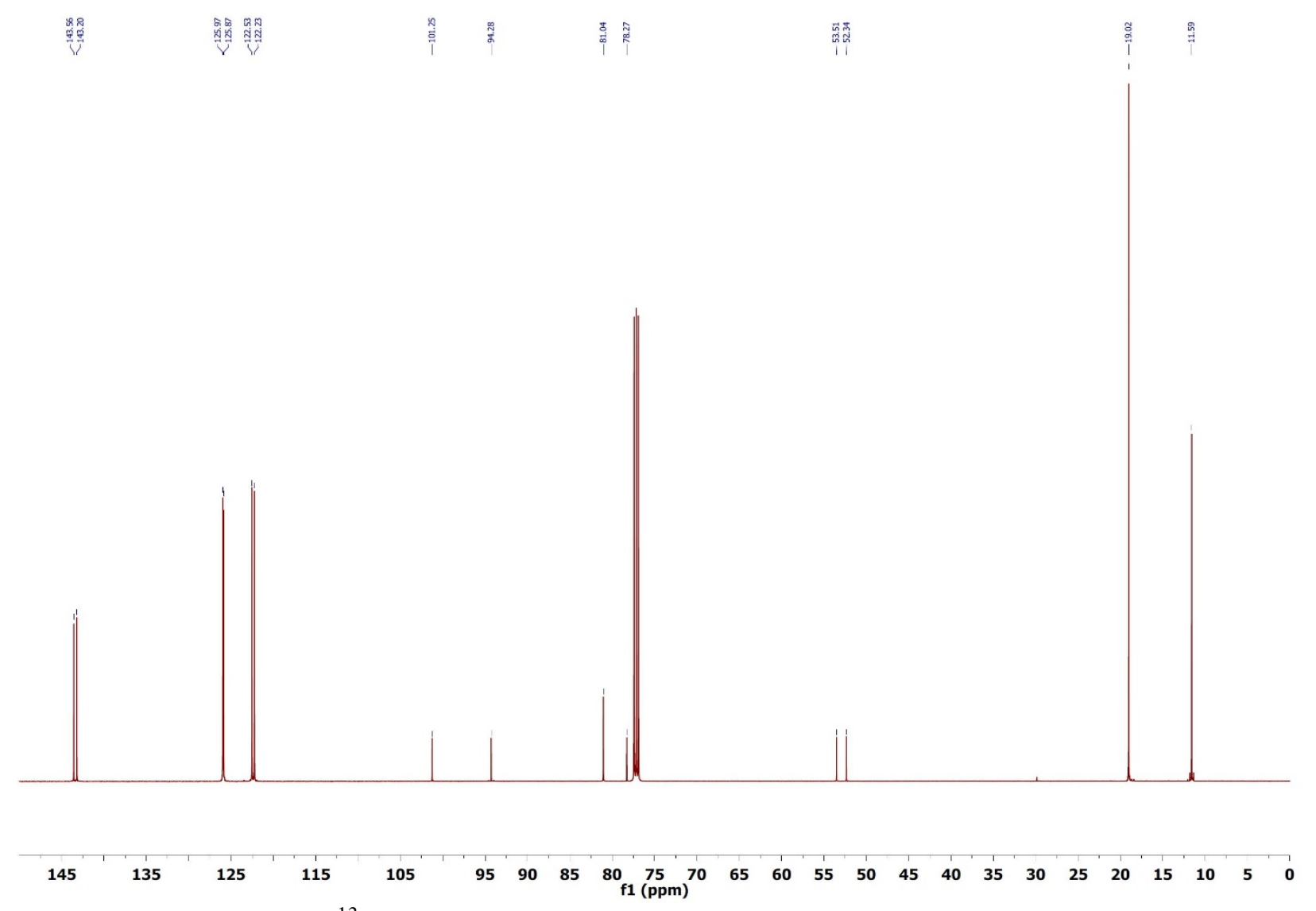

Figure S2. ${ }^{13} \mathrm{C}$ NMR spectrum of compound 12 at $126 \mathrm{MHz}$ in $\mathrm{CDCl}_{3}$.

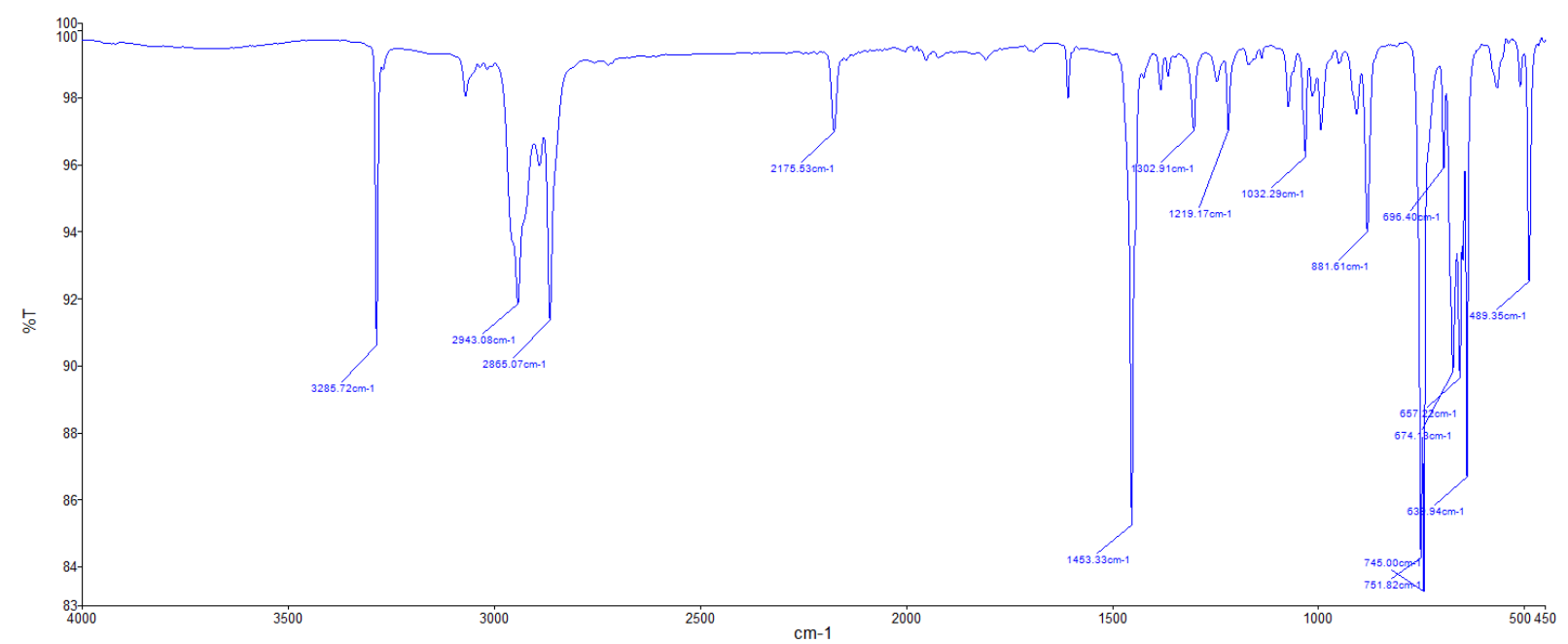

Figure S3. FTIR Spectrum of compound 12a taken as a powder. 

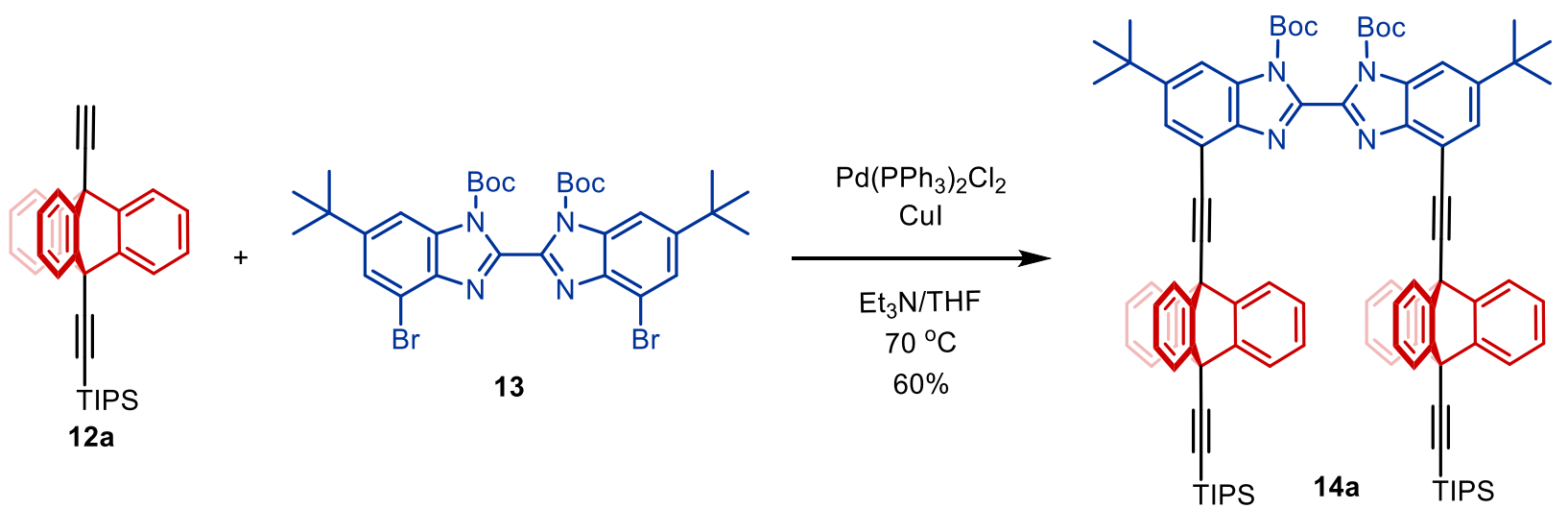

To an argon-flushed solid mixture of 12a (400 mg, $0.872 \mathrm{mmol}), \mathbf{1 3}$ (292.5 mg, $0.415 \mathrm{mmol})$, $\mathrm{CuI}(15.8 \mathrm{mg}, 83 \mu \mathrm{mol})$, and $\mathrm{Pd}\left(\mathrm{PPh}_{3}\right)_{2} \mathrm{Cl}_{2}(29.2 \mathrm{mg}, 41.5 \mu \mathrm{mol})$ were added. The flask was then charged with degassed, dry THF $(10 \mathrm{~mL})$ and degassed triethylamine $(10 \mathrm{~mL})$. The reaction mixture was stirred and heated to $70^{\circ} \mathrm{C}$. After $18 \mathrm{~h}$, the solvents were removed from the reaction mixture and the remaining solid was subjected to column chromatography (alumina, hexane $\left./ \mathrm{CH}_{2} \mathrm{Cl}_{2}=9.5: 0.5-9: 1\right)$, giving $\mathbf{1 4 a}$ as a white solid $(360 \mathrm{mg}, 60 \%)$.

Rf 0.6 (alumina, 2:8 $\mathrm{CH}_{2} \mathrm{Cl}_{2}: \mathrm{Hexane)}$;

'H NMR (500 MHz, $\left.\mathrm{CDCl}_{3}\right) \delta 8.27(\mathrm{~d}, J=1.8 \mathrm{~Hz}, 2 \mathrm{H}), 8.06-8.00(\mathrm{~m}, 6 \mathrm{H}), 7.95(\mathrm{~d}, J=1.8 \mathrm{~Hz}$, $2 \mathrm{H}), 7.77-7.72(\mathrm{~m}, 6 \mathrm{H}), 7.06-7.00(\mathrm{~m}, 12 \mathrm{H}), 1.54(\mathrm{~s}, 18 \mathrm{H}), 1.45(\mathrm{~s}, 18 \mathrm{H}), 1.36-1.27(\mathrm{~m}$, $42 \mathrm{H})$;

"C NMR (126 MHz, $\left.\mathrm{CDCl}_{3}\right) \delta 149.77,148.02,144.60,143.76,143.54,142.21,133.13,126.72$, $125.89,125.68,122.97,122.25,114.98,112.71,101.61,93.89,89.67,88.19,85.80,53.54,53.37$, $35.61,31.95,27.95,19.01,11.59$;

IR (Film) 2952.09, 2864.88, 1750.49, 1606.98, 1454.51, 1403.52, 1357.15, 1305.99, 1293.24, $1250.44,1234.33,1129.21,1048.77,1031.73,907.89,878.92,843.52,752.16,731.88,697.08$, $677.22,667.15,639.77,582.03,488.75 \mathrm{~cm}^{\prime}$;

HRMS (MALDI) Calcd for $\mathrm{C}_{98} \mathrm{H}_{100} \mathrm{~N}_{4} \mathrm{O}_{4} \mathrm{Si}_{2}$ with loss of $2 \mathrm{x} \mathrm{Boc}+\mathrm{Na}^{+}$(1281.6602) Found: 1281.6366 . 


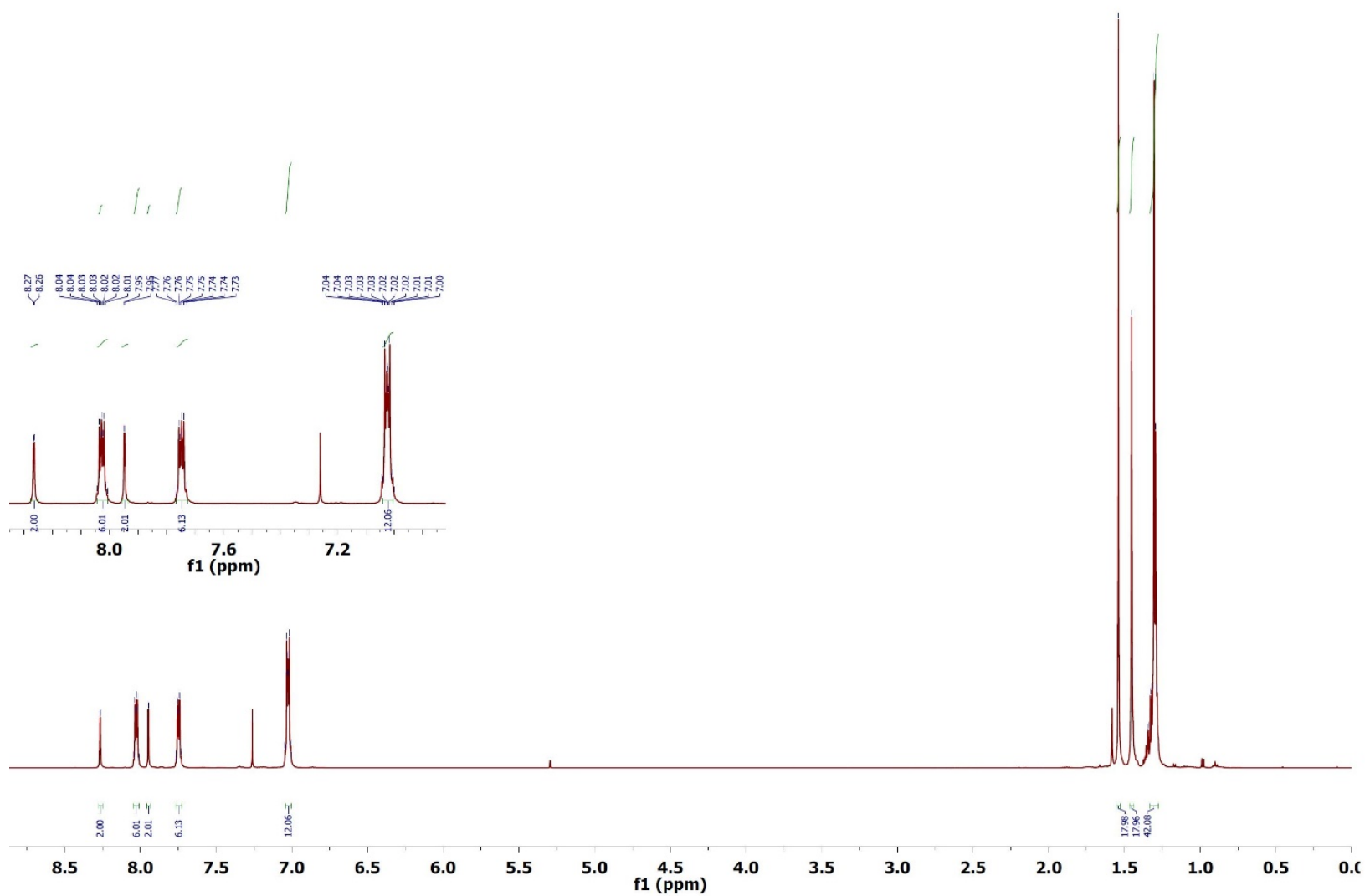

Figure S4. ${ }^{1} \mathrm{H}$ NMR spectrum of compound $14 a$ at $500 \mathrm{MHz}$ in $\mathrm{CDCl}_{3}$. 

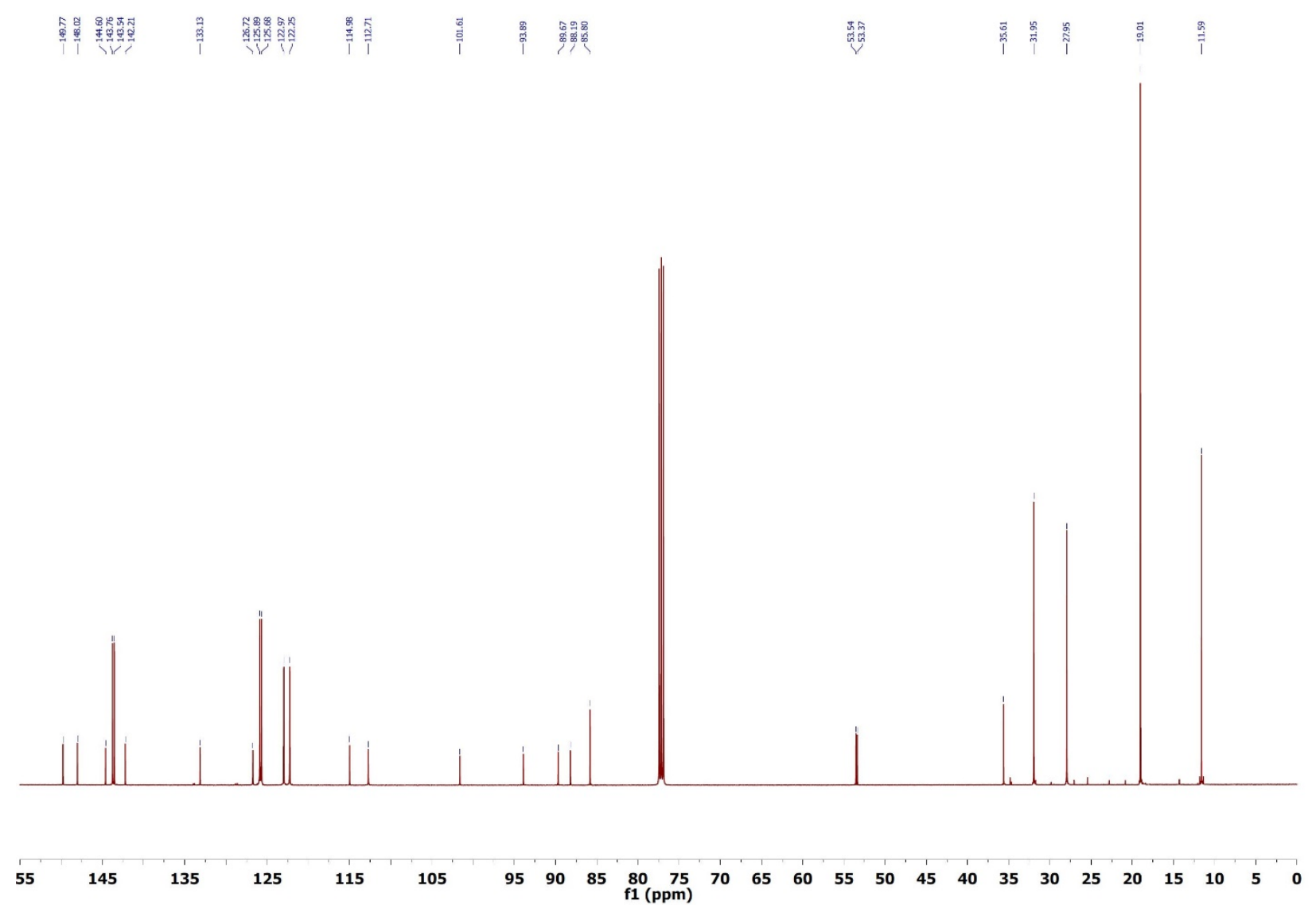

Figure S5. ${ }^{13} \mathrm{C}$ NMR specrtum of compound $14 \mathbf{a}$ at $126 \mathrm{MHz}$ in $\mathrm{CDCl}_{3}$.

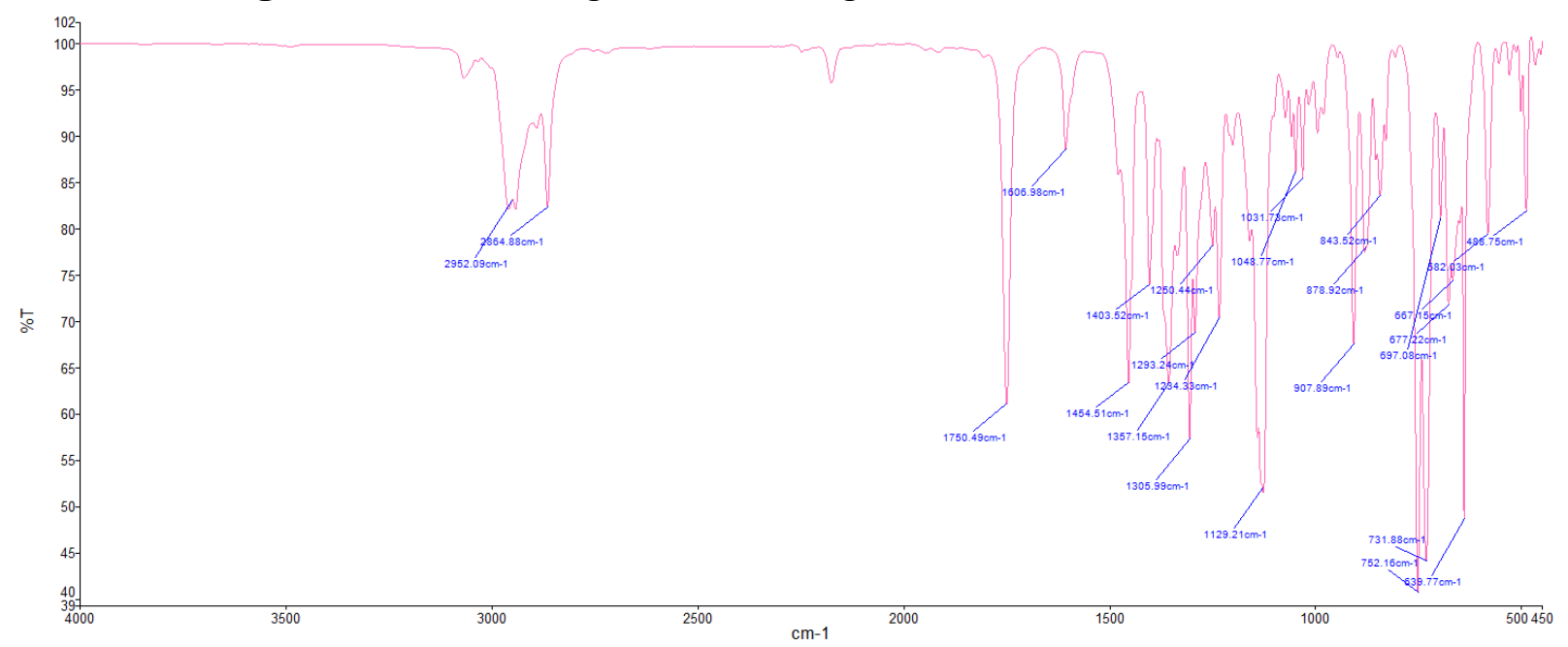

Figure S6. FTIR Spectrum of compound 14a taken as a powder. 


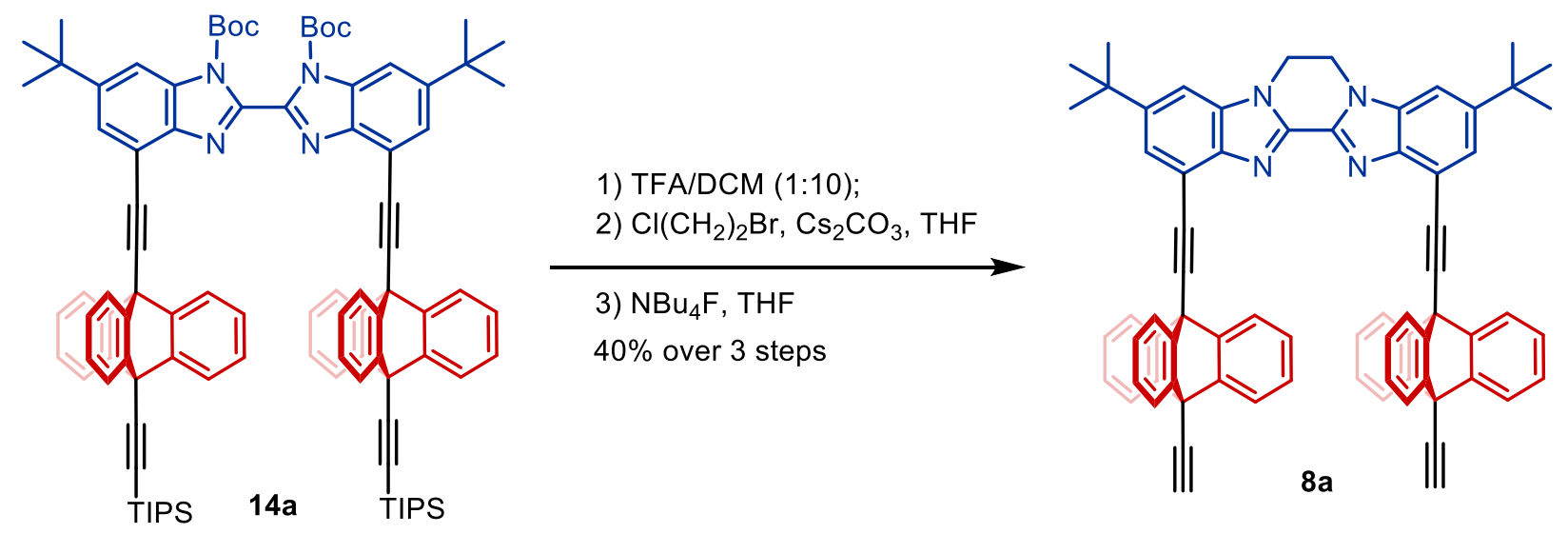

To a solution of $14 \mathbf{a}(300 \mathrm{mg}, 0.205 \mathrm{mmol})$ in $\mathrm{CH}_{2} \mathrm{Cl}_{2}(4 \mathrm{~mL})$ under air was added trifluoroacetic acid $(0.45 \mathrm{~mL})$. The reaction mixture was stirred at room temperature for $3 \mathrm{~h}$, after which water, sat. $\mathrm{NaHCO}_{3}$ solution was added until the solution was neutralized. The layers were separated and the aqueous phase was extracted with $\mathrm{CH}_{2} \mathrm{Cl}_{2}$. The combined organic phases were washed with saturated $\mathrm{NaCl}$ solution and dried over $\mathrm{MgSO}_{4}$, and concentrated, affording crude 4,4'bis(triptycen-9-ylethynyl)-6,6'-di-tert-butyl-2,2'-bibenzimidazole as a white solid (258 mg), which was used directly in the next step.

Crude 4,4'-bis(triptycen-9-ylethynyl)-6,6'-di-tertbutyl-2,2'-bibenzimidazole (260. $\mathrm{mg}, 21$ $\mu \mathrm{mol})$ was dissolved in THF $(5 \mathrm{~mL})$. To this solution, $\mathrm{Cs}_{2} \mathrm{CO}_{3}(201 . \mathrm{mg}, 617 \mu \mathrm{mol})$ and excess 1 bromo-2-chloroethane $(5 \mathrm{~mL})$ were added. The reaction mixture was stirred for $17 \mathrm{~h}$ at $60{ }^{\circ} \mathrm{C}$. Water and $\mathrm{CH}_{2} \mathrm{Cl}_{2}$ were added and the layers were separated. The aqueous phase was extracted with $\mathrm{CH}_{2} \mathrm{Cl}_{2}$ and the combined organic phases were washed with sat. $\mathrm{NaCl}$, dried with $\mathrm{MgSO}_{4}$ and concentrated in vacuo. The resulting residue was subjected to column chromatography $\left(\mathrm{SiO}_{2}\right.$, hexane/EtOAc = 7:3 - 1:1) giving $156 \mathrm{mg}$ of white powder.

$135 \mathrm{mg}$ of the resultant compound was added to a $50 \mathrm{~mL}$ round bottom flask and placed under argon. $25 \mathrm{~mL}$ of dry THF was then added to the solution and the mixture was cooled to $-78{ }^{\circ} \mathrm{C}$. Subsequently, $0.22 \mathrm{~mL}$ of $1 \mathrm{M}$ TBAF in THF was added to the solution and then the mixture was allowed to warm to $0{ }^{\circ} \mathrm{C}$. The mixture then stirred for 15 minutes before being quenched with a saturated $\mathrm{NH}_{4} \mathrm{Cl}$ solution. The mixture was then extracted 3 times with $20 \mathrm{~mL} \mathrm{CH}_{2} \mathrm{Cl}_{2}$ and the organic phase was dried over $\mathrm{MgSO}_{4}$ and concentrated. The crude mixture was purified with column chromatography ( $\mathrm{SiO}_{2}$, hexane/EtOAc 1:1) to yield $75 \mathrm{mg}$ of $\mathbf{8 a}$ as a white, crystalline powder (44\% yield over three steps).

Rf $0.38\left(\mathrm{SiO}_{2}, 1: 2\right.$ EtOAc:Hexane);

'H NMR (500 MHz, $\left.\mathrm{CDCl}_{3}\right) \delta 8.11(\mathrm{~d}, J=7.3 \mathrm{~Hz}, 6 \mathrm{H}), 7.85(\mathrm{~d}, J=1.5 \mathrm{~Hz}, 2 \mathrm{H}), 7.68(\mathrm{~d}, J=7.3$ $\mathrm{Hz}, 6 \mathrm{H}), 7.50(\mathrm{~d}, J=1.5 \mathrm{~Hz}, 2 \mathrm{H}), 6.98(\mathrm{td}, J=7.4,0.8 \mathrm{~Hz}, 6 \mathrm{H}), 6.78(\mathrm{td}, J=7.4,0.8 \mathrm{~Hz}, 6 \mathrm{H})$, $4.73(\mathrm{~s}, 4 \mathrm{H}), 3.29(\mathrm{~s}, 2 \mathrm{H}), 1.53(\mathrm{~s}, 18 \mathrm{H})$;

"C NMR (126 MHz, $\left.\mathrm{CDCl}_{3}\right) \delta 148.11,143.74,143.70,143.02,142.19,134.46,126.14,126.01$, 125.62, 123.04, 121.93, 115.27, 106.59, 90.01, 88.18, 80.76, 78.60, 53.45, 52.37, 40.93, 35.45, 31.98;

IR (film) 3298.91, 3067.63, 2959.62, 2925.25, 2866.75, 1727.8, 1608.51, 1454.17, 1420.65, $1379.59,1363.8,1337.83,1326.83$, 1306.01, 1255.35, 1233.56, 1202.06, 1155.91, 1079.35, 1031.93, 908.13, 879.05, 849.32, 803.65, 753.62, 732.48, 654.81, 640.02, 576.94, $486.8 \mathrm{~cm}^{-1}$; 
HRMS (APCI) Calcd for $\mathrm{C}_{72} \mathrm{H}_{52} \mathrm{~N}_{4}(\mathrm{M}+1)$ 973.42647, found 973.4275.

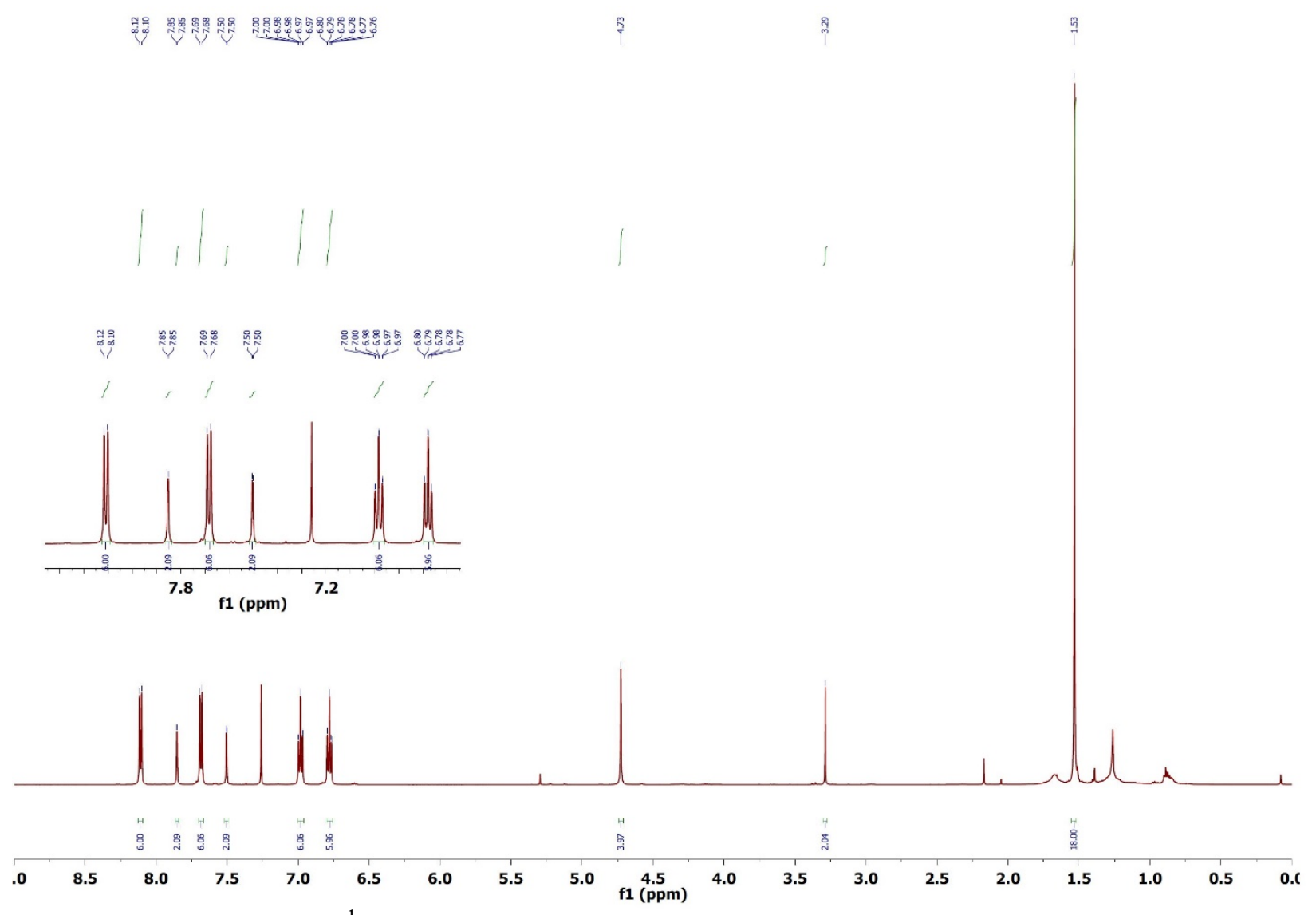

Figure S7. ${ }^{1} \mathrm{H}$ NMR spectrum of compound $8 \mathbf{a}$ at $500 \mathrm{MHz}$ in $\mathrm{CDCl}_{3}$. 

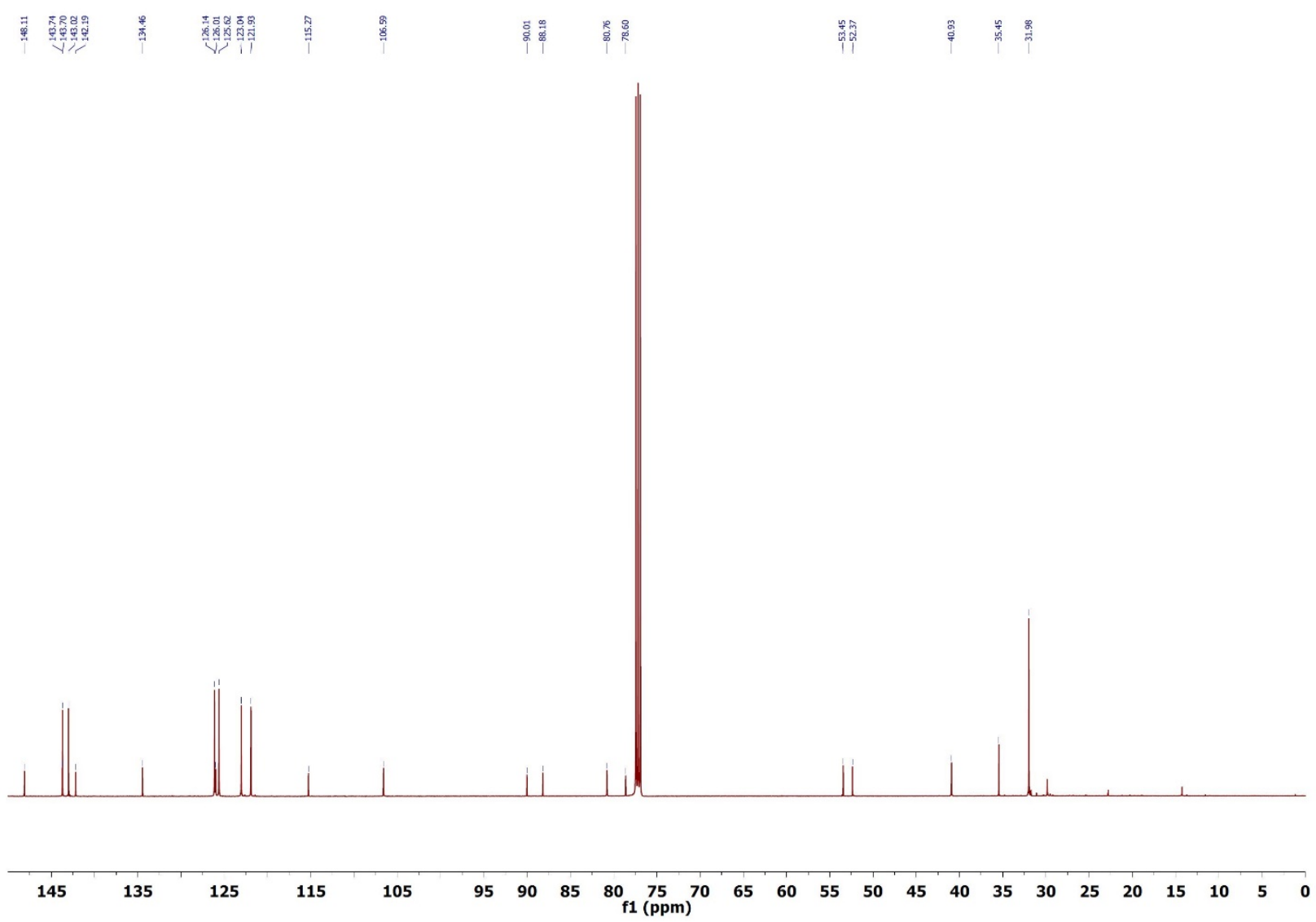

Figure S8. ${ }^{13} \mathrm{C}$ NMR spectrum of compound 8a at $126 \mathrm{MHz}$ in $\mathrm{CDCl}_{3}$.

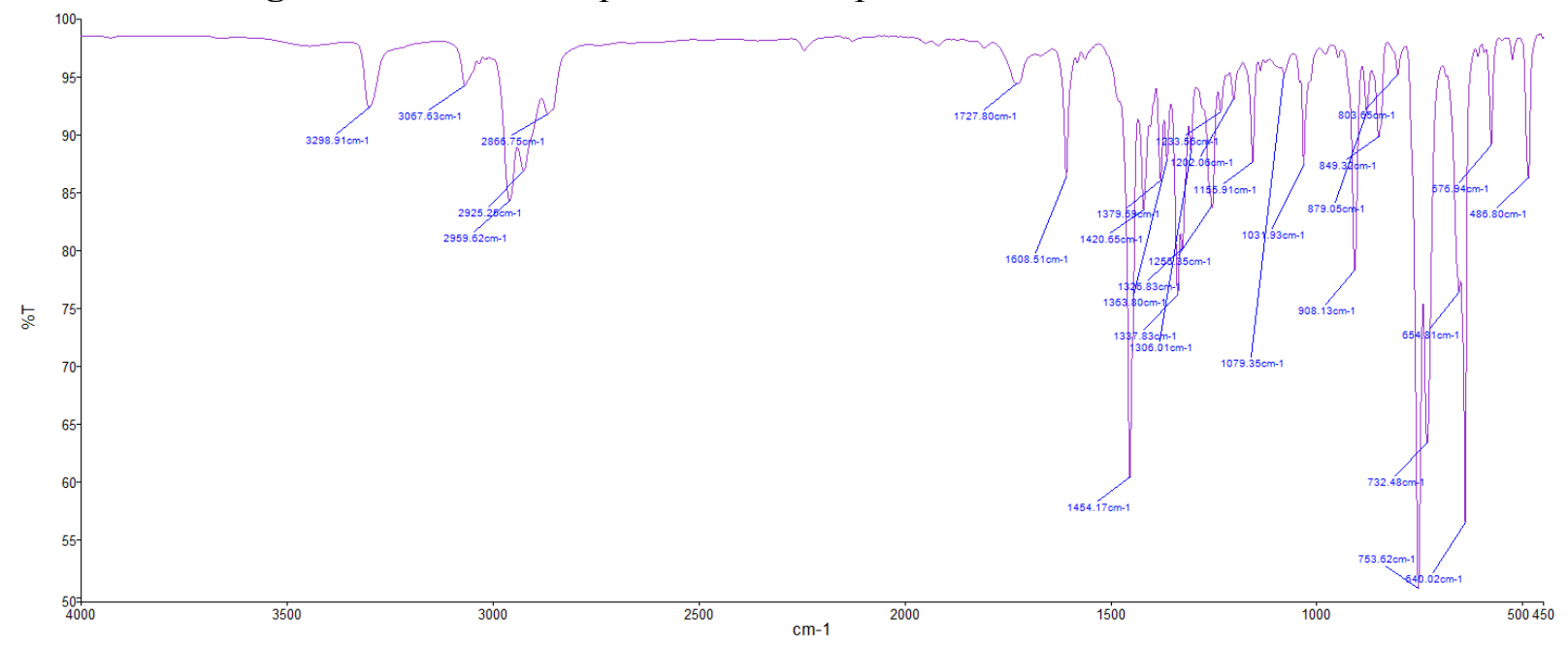

Figure S9. FTIR Spectrum of compound 8a taken as a powder. 


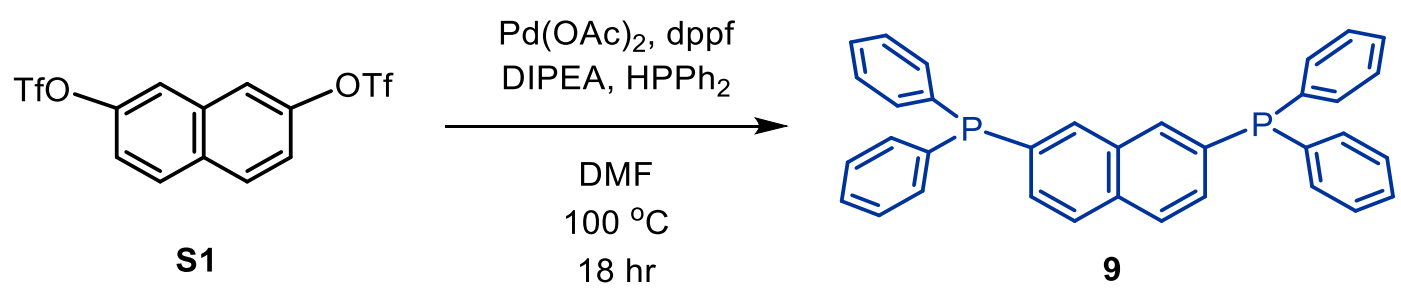

A $25 \mathrm{~mL}$ Schlenk flask was charged with dppf $(33.17 \mathrm{mg}, 0.077 \mathrm{mmol}), \operatorname{Pd}(\mathrm{OAc})_{2}(15.9 \mathrm{mg}$, $0.071 \mathrm{mmol}$ ) and placed under an argon atmosphere. Subsequently, $3 \mathrm{~mL}$ of argon sparged DMF and $2 \mathrm{~mL}$ of argon sparged DIPEA were added to the flask and the solution was stirred for $1 \mathrm{hr}$. $\mathrm{HPPh}_{2}(0.492 \mathrm{~mL}, 2.83 \mathrm{mmol})$ was then added and the mixture was stirred for an additional 5 minutes. Finally, $\mathbf{S 1}(300 \mathrm{mg}, 0.71 \mathrm{mmol})$ dissolved in $2 \mathrm{~mL}$ of argon sparged DMF was slowly syringed into the mixture and the mixture was stirred overnight at $100{ }^{\circ} \mathrm{C}$. After this time, the crude solution was cooled to room temperature and $10 \mathrm{~mL}$ of water was added. This mixture was then extracted 3 times with $\mathrm{CH}_{2} \mathrm{Cl}_{2}(20 \mathrm{~mL})$, and the combined organic layers were dried over $\mathrm{MgSO}_{4}$ then concentrated in vacuo. The crude compound was columned using silica as the stationary phase and a 1:2 mixture of $\mathrm{CH}_{2} \mathrm{Cl}_{2}:$ Hexane to yield $300 \mathrm{mg}$ of $\mathbf{9}$ (85\% yield).

Rf $0.33\left(\mathrm{SiO}_{2}, 1: 1 \mathrm{CH}_{2} \mathrm{Cl}_{2}:\right.$ Hexane);

1H NMR (500 MHz, $\left.\mathrm{CDCl}_{3}\right) \delta 7.78(\mathrm{t}, \mathrm{J}=7.5 \mathrm{~Hz}, 4 \mathrm{H}), 7.43-7.40(\mathrm{~m}, 2 \mathrm{H}), 7.39-7.34(\mathrm{~m}$, $20 \mathrm{H})$;

13C NMR (126 MHz, CDCl3) $\delta 136.98,136.90,135.46,135.37,134.66,134.46,133.96$, 133.81, 133.40, 133.25, 133.18, 131.03, 130.90, 128.98, 128.73, 128.68, 127.93, 127.88;

IR (film) 3050.95, 1584.51, 1477.6, 1433, 1316.28, 1272.23, 1183.22, 1087.18, 1069.26, 1026.36, 999.36, 946.92, 907.56, 842.81, 738.61, 694.06, 651.48, 565, 491.16, $477.2 \mathrm{~cm}$;

HRMS (APCI) Calcd for $\mathrm{C}_{34} \mathrm{H}_{20} \mathrm{P}_{2}(\mathrm{M}+1)$ 497.15996, found 497.15825. 


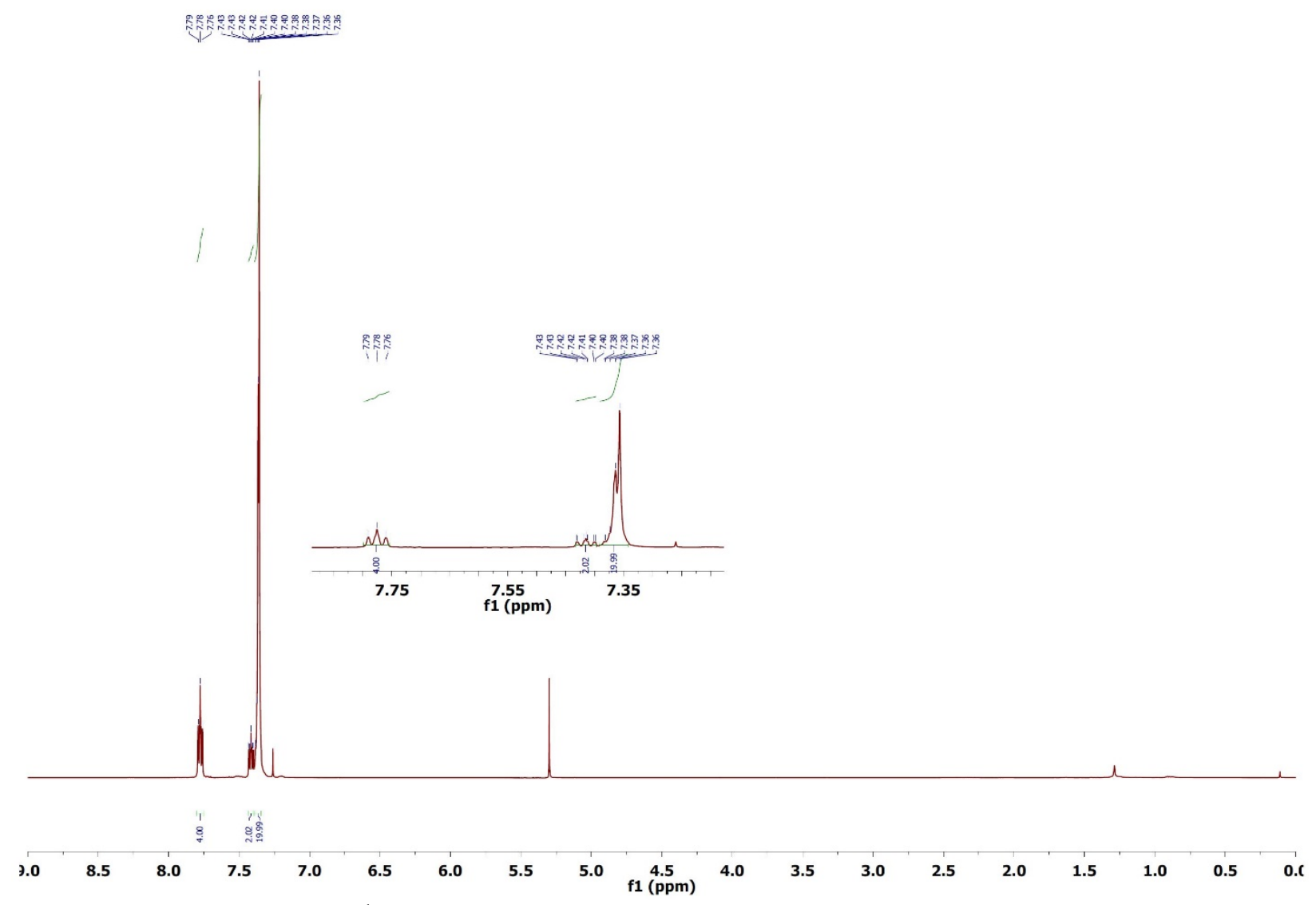

Figure S10. ${ }^{1} \mathrm{H}$ NMR spectrum of compound 9 at $500 \mathrm{MHz}$ in $\mathrm{CDCl}_{3}$. 

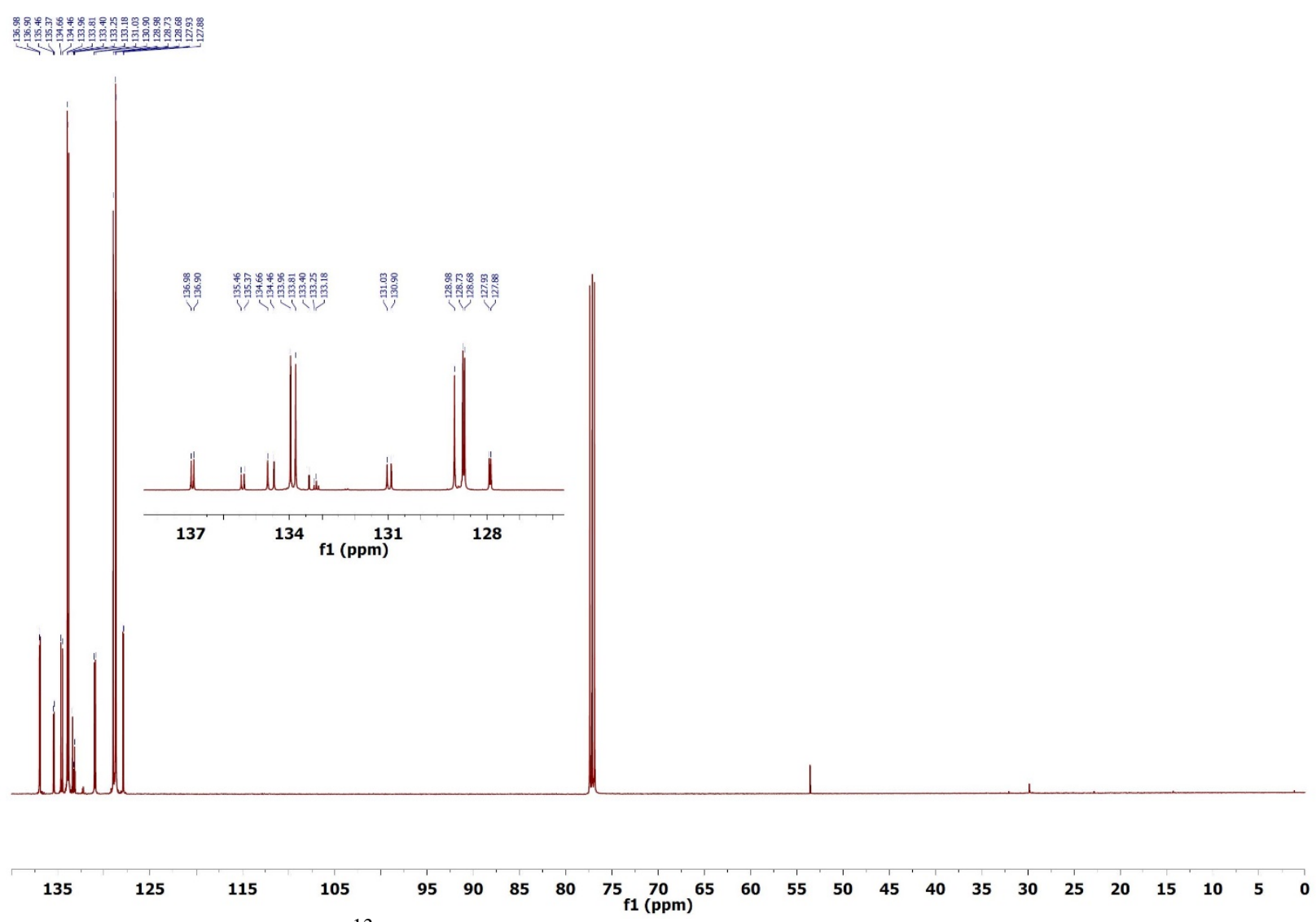

Figure S11. ${ }^{13} \mathrm{C}$ NMR spectrum of compound 9 at $126 \mathrm{MHz}$ in $\mathrm{CDCl}_{3}$.

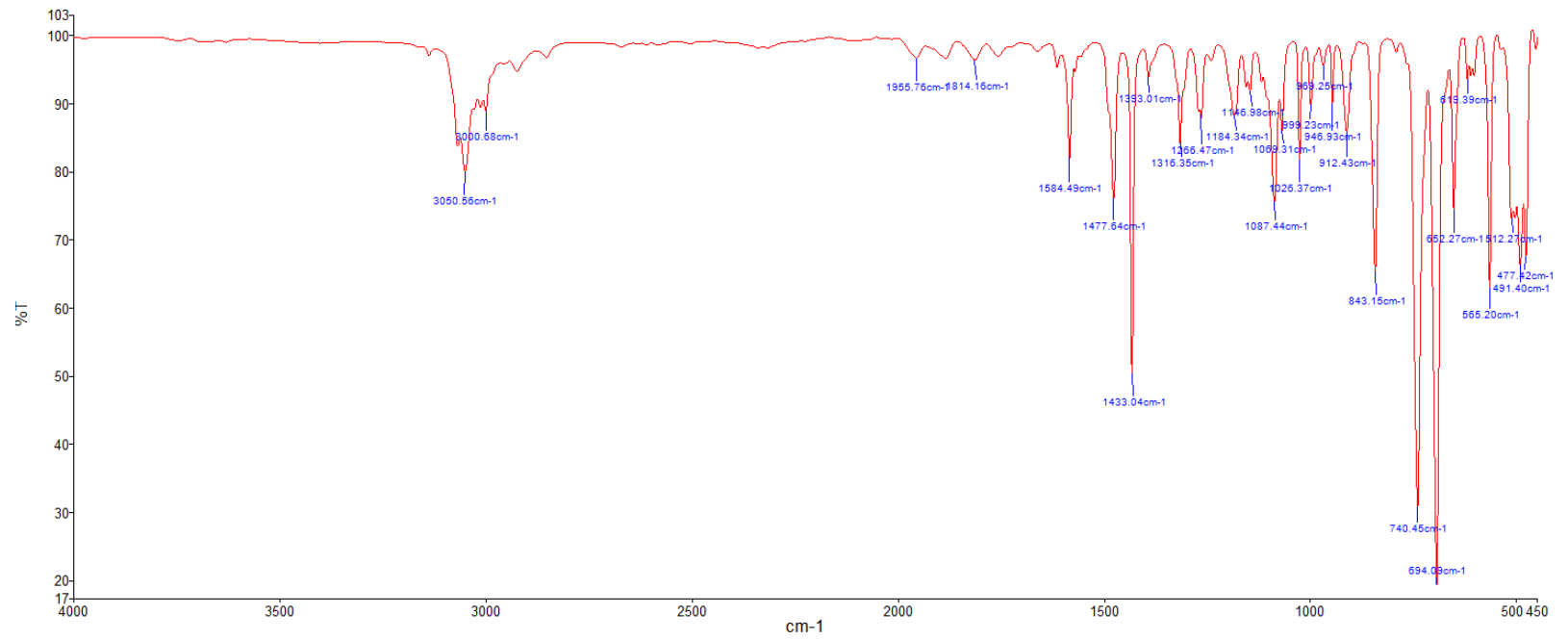

Figure S12. FTIR Spectrum of compound 9 taken as a powder. 

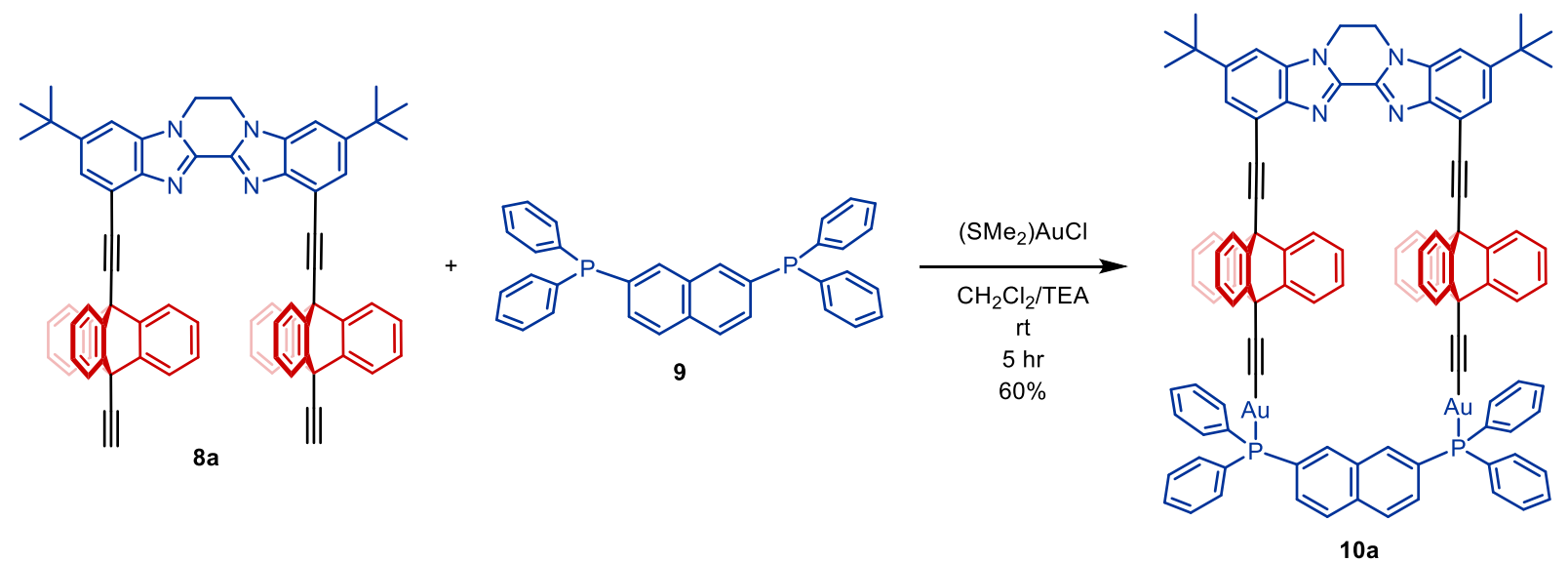

8a (10 mg, $0.010 \mathrm{mmol}$ ) was dissolved in $5 \mathrm{~mL}$ of $\mathrm{CH}_{2} \mathrm{Cl}_{2}$ and added to a $25 \mathrm{~mL}$ round bottomed flask. $\left(\mathrm{SMe}_{2}\right) \mathrm{AuCl}(6.05 \mathrm{mg}, 0.020 \mathrm{mmol})$ dissolved in $5 \mathrm{~mL} \mathrm{CH}_{2} \mathrm{Cl}_{2}$ was then added followed by 1 drop of triethylamine. This mixture was stirred for 15 min to allow complexation to occur, which can be convenient monitored by the disappearance of $8 \mathbf{a}$ on TLC. After this, 9 (5.10 $\mathrm{mg}$, $0.01 \mathrm{mmol}$ ) dissolved in $5 \mathrm{~mL}$ of $\mathrm{CH}_{2} \mathrm{Cl}_{2}$ was added dropwise and the final mixture was stirred for 3 hrs. Additional 9 could be titrated into the mixture if complete conversion of $\mathbf{8 a}$ into 10a did not proceed efficiently. After completion of the reaction, the mixture was run through a small silica plug and rinsed multiple times with $\mathrm{CH}_{2} \mathrm{Cl}_{2}$. This mixture was then concentrated in vacuo to yield a crude yellow colored paste. This paste was then dissolved in $3 \mathrm{~mL} \mathrm{CH}_{2} \mathrm{Cl}_{2}$ and then $5 \mathrm{~mL}$ of hexane and $1 \mathrm{~mL}$ of $\mathrm{MeOH}$ was added to crashed 10a out of solution. This heterogeneous mixture was then centrifuged and the solvent mixture was removed. This powder was then washed with $3 \mathrm{~mL}$ of $\mathrm{CH}_{2} \mathrm{Cl}_{2}$ and $6 \mathrm{~mL}$ of hexane 3 more times with centrifugation between each step. After completion of these purifications, the white powder was dried to yield $11.6 \mathrm{mg}$ of 10a (60\% yield).

\section{Rf $0.25\left(\mathrm{SiO}_{2}, 4: 1 \mathrm{CH}_{2} \mathrm{Cl}_{2}:\right.$ Hexane $)$;}

$\mathrm{mp} 420^{\circ} \mathrm{C}$ (decomposition);

'H NMR (500 MHz, $\left.\mathrm{CD}_{2} \mathrm{Cl}_{2}\right) \delta 9.23(\mathrm{~d}, J=17.0 \mathrm{~Hz}, 2 \mathrm{H}), 8.06(\mathrm{~d}, J=7.3 \mathrm{~Hz}, 6 \mathrm{H}), 8.01(\mathrm{~d}, J=$ $8.4 \mathrm{~Hz}, 2 \mathrm{H}), 7.92(\mathrm{~s}, 2 \mathrm{H}), 7.88(\mathrm{~d}, J=7.3 \mathrm{~Hz}, 6 \mathrm{H}), 7.72(\mathrm{dd}, J=11.8,7.4 \mathrm{~Hz}, 8 \mathrm{H}), 7.61(\mathrm{~s}, 2 \mathrm{H})$, $7.58(\mathrm{~m}, J=7.6 \mathrm{~Hz}, 12 \mathrm{H}), 7.47(\mathrm{t}, J=8.6 \mathrm{~Hz}, 2 \mathrm{H}), 6.87(\mathrm{t}, J=7.3 \mathrm{~Hz}, 6 \mathrm{H}), 6.59(\mathrm{t}, J=7.4 \mathrm{~Hz}$, $6 \mathrm{H}), 4.80(\mathrm{~s}, 4 \mathrm{H}), 1.55(\mathrm{~s}, 18 \mathrm{H})$;

IR (film) 2957.37, 1708.72, 1607.37, 1454.16, 1436.85, 1419.51 1379.36, 1362.69, 1332.35, 1253.49, 1155.56, 1099.04, 1029.69, 998.79, 916.45, 877.64, 845.43, 749.41, 692.21, 659.93, $639.66,621.71,565.91,537.91,489.27 \mathrm{~cm}^{-1}$;

HRMS (ESI) Calcd for $\mathrm{C}_{106} \mathrm{H}_{76} \mathrm{Au}_{2} \mathrm{~N}_{4} \mathrm{P}_{2}(\mathrm{M}+\mathrm{H})$ 1861.4955, found 1861.4944. 


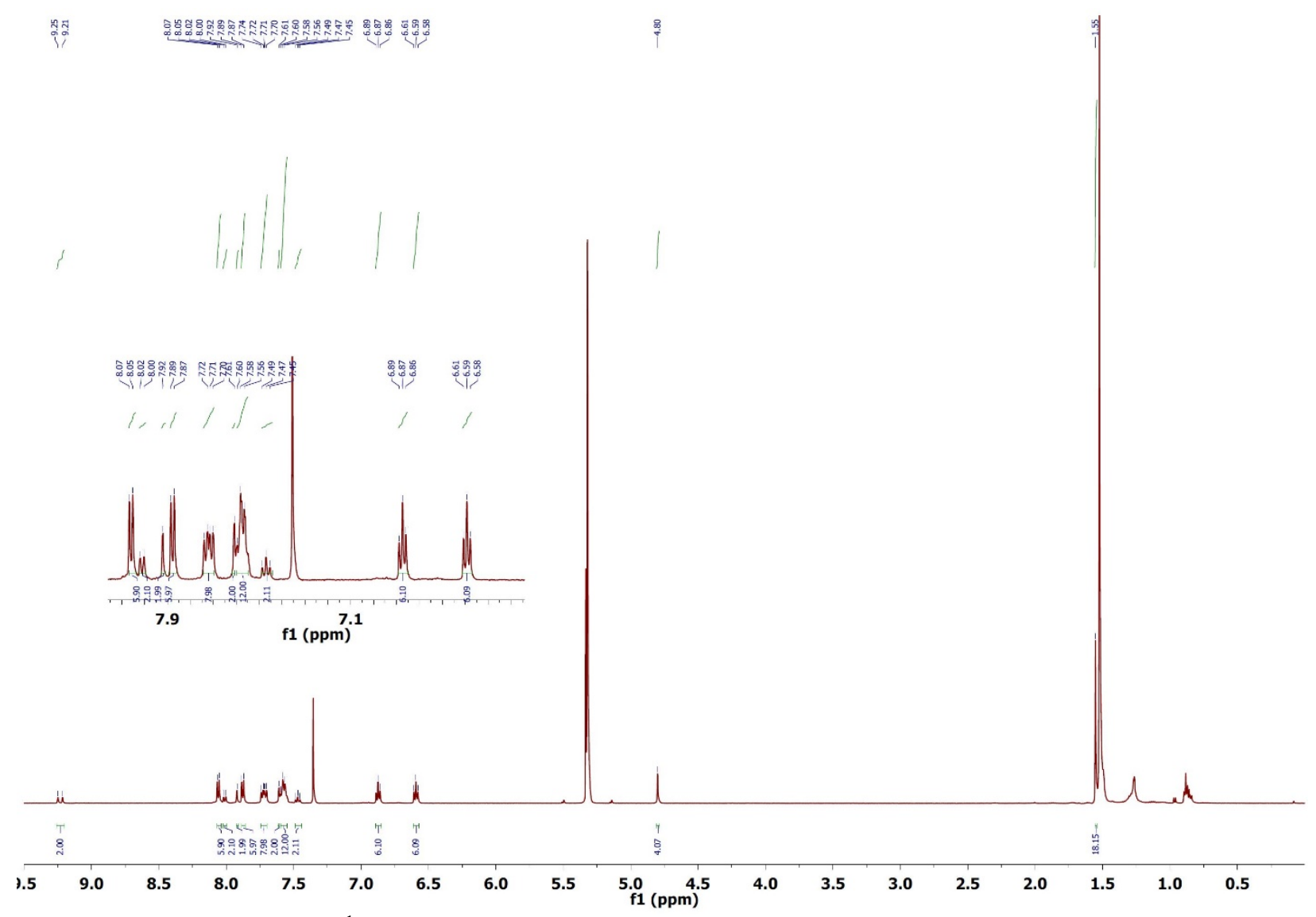

Figure S13. ${ }^{1} \mathrm{H}$ NMR spectrum of compound $\mathbf{1 0 a}$ at $500 \mathrm{MHz}$ in $\mathrm{CD}_{2} \mathrm{Cl}_{2}$.

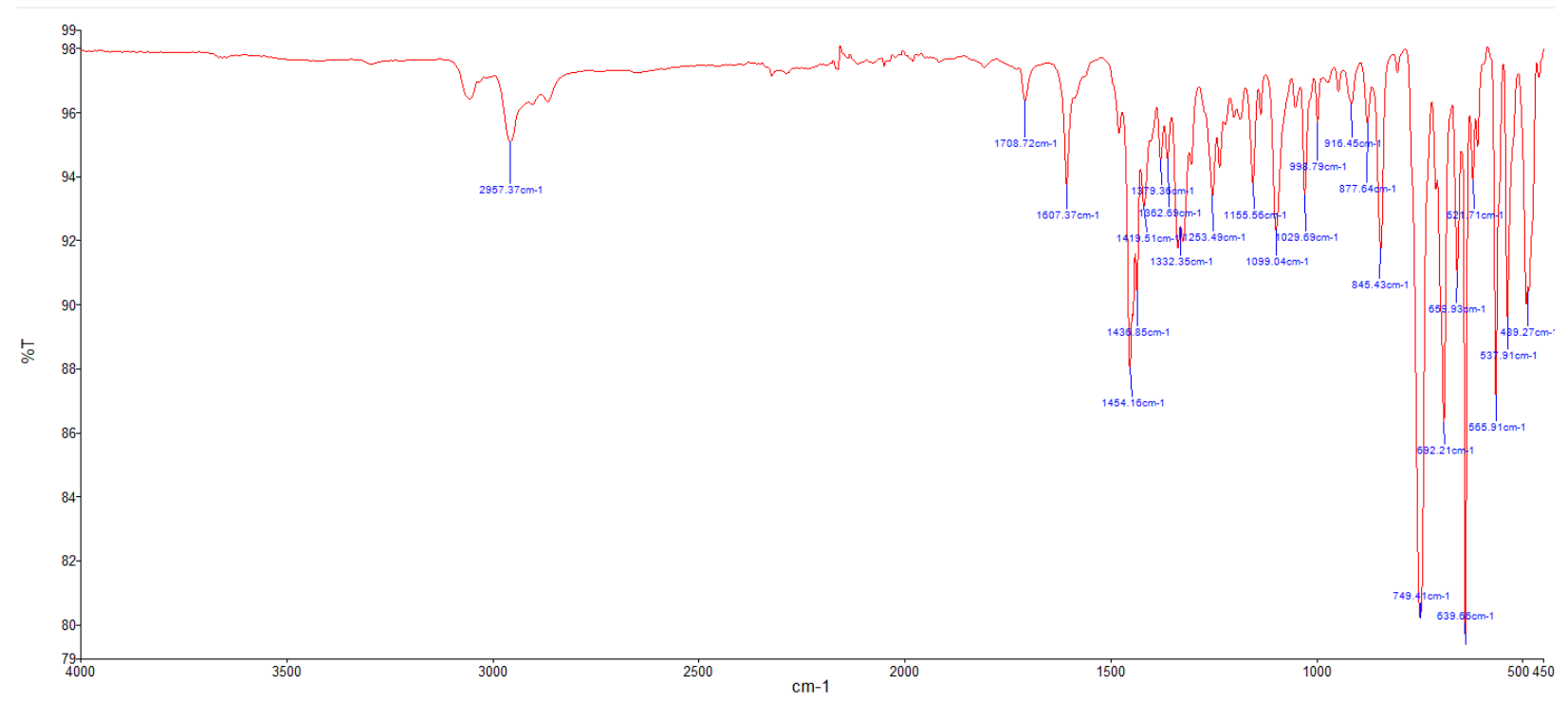

Figure S14. FTIR Spectrum of compound 10a taken as a powder. 

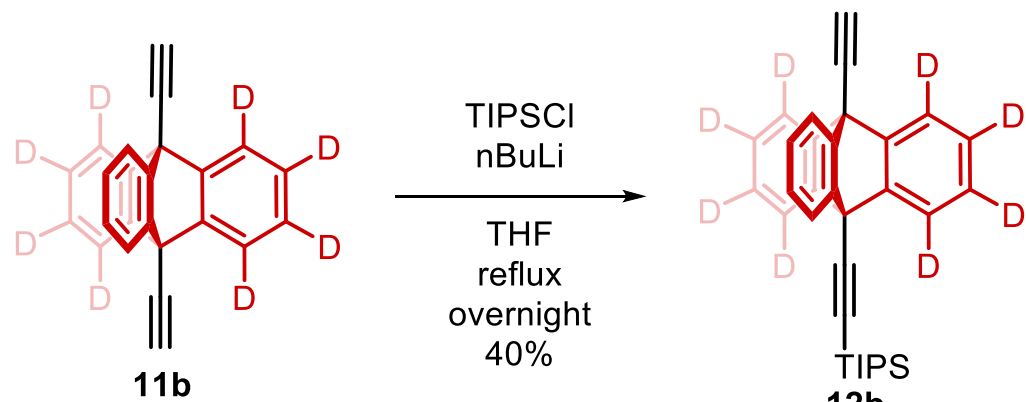

$12 b$

A $50 \mathrm{~mL}$ round bottom flask was charged with dialkyne $\mathbf{1 1 b}(600 \mathrm{mg}, 1.93 \mathrm{mmol})$ and placed under an inert argon atmosphere. $15 \mathrm{~mL}$ of THF were then added and the solution was cooled to $-78{ }^{\circ} \mathrm{C}$. n-butyllithium $(0.775 \mathrm{~mL}, 1.93 \mathrm{mmol})$ was then added to the flask and the mixture was stirred for 30 minutes. Triisopropylsilyl chloride $(0.42 \mathrm{~mL}, 2.20 \mathrm{mmol})$ was then added to the flask and the reaction mixture was first warmed to room temperature and then brought to reflux overnight. The mixture was then cooled to room temperature and quenched with saturated ammonium chloride solution. The resultant solution was extracted three times with DCM (10 $\mathrm{mL}$ ), dried over $\mathrm{MgSO}_{4}$, and concentrated to yield a white powder. Purification of the crude mixture was accomplished by flash chromatography ( $\mathrm{SiO}_{2}$, Hexanes) to yield $430 \mathrm{mg}$ of pure monoprotected product (44\% yield) as a white solid. Diprotected and unprotected products were combined, deprotected with tetrabutylammonium fluoride and purified with a hexane column to be reused in subsequent reactions.

Rf 0.37 (Silica, Hexane);

'H NMR (500 MHz, $\left.\mathrm{CDCl}_{3}\right) \delta 8.62(\mathrm{dd}, J=9.5,5.4 \mathrm{~Hz}, 2 \mathrm{H}), 8.20(\mathrm{dd}, J=10.5,2.5 \mathrm{~Hz}, 2 \mathrm{H})$, 7.43 (ddd, $J=10.0,7.8,2.5 \mathrm{~Hz}, 2 \mathrm{H}), 1.36-1.21(\mathrm{~m}, 42 \mathrm{H})$;

C NMR (126 MHz, $\left.\mathrm{CDCl}_{3}\right)$ 143.58, 143.50, 143.22, 143.14, 125.96, 125.86, 125.74, 125.64, $125.54,125.45,125.35,125.26,125.16,122.52,122.41,122.32,122.22,122.13,122.03,121.94$, $121.84,121.64,101.28,94.17,80.95,78.29,53.44,52.27,19.01,11.59$;

IR (Film) 3285.72, 2943.08, 2890.66, 2865.08, 2277.2, 2172.2, 1601.37, 1578.39, 1467.68, $1387.81,1358.9,1289.62,1229.19,1058.76,1016.05,992.16,917.8,882.46,810.28,744.47$, 674.17, 657.05, 621.2, 583.76, 577, 509.82, 478.7, $455.83 \mathrm{~cm}^{-1}$;

HRMS (APCI) Calcd for $\mathrm{C}_{33} \mathrm{H}_{26} \mathrm{D}_{8} \mathrm{Si}$ (M) 466.29341, found 466.29264. 


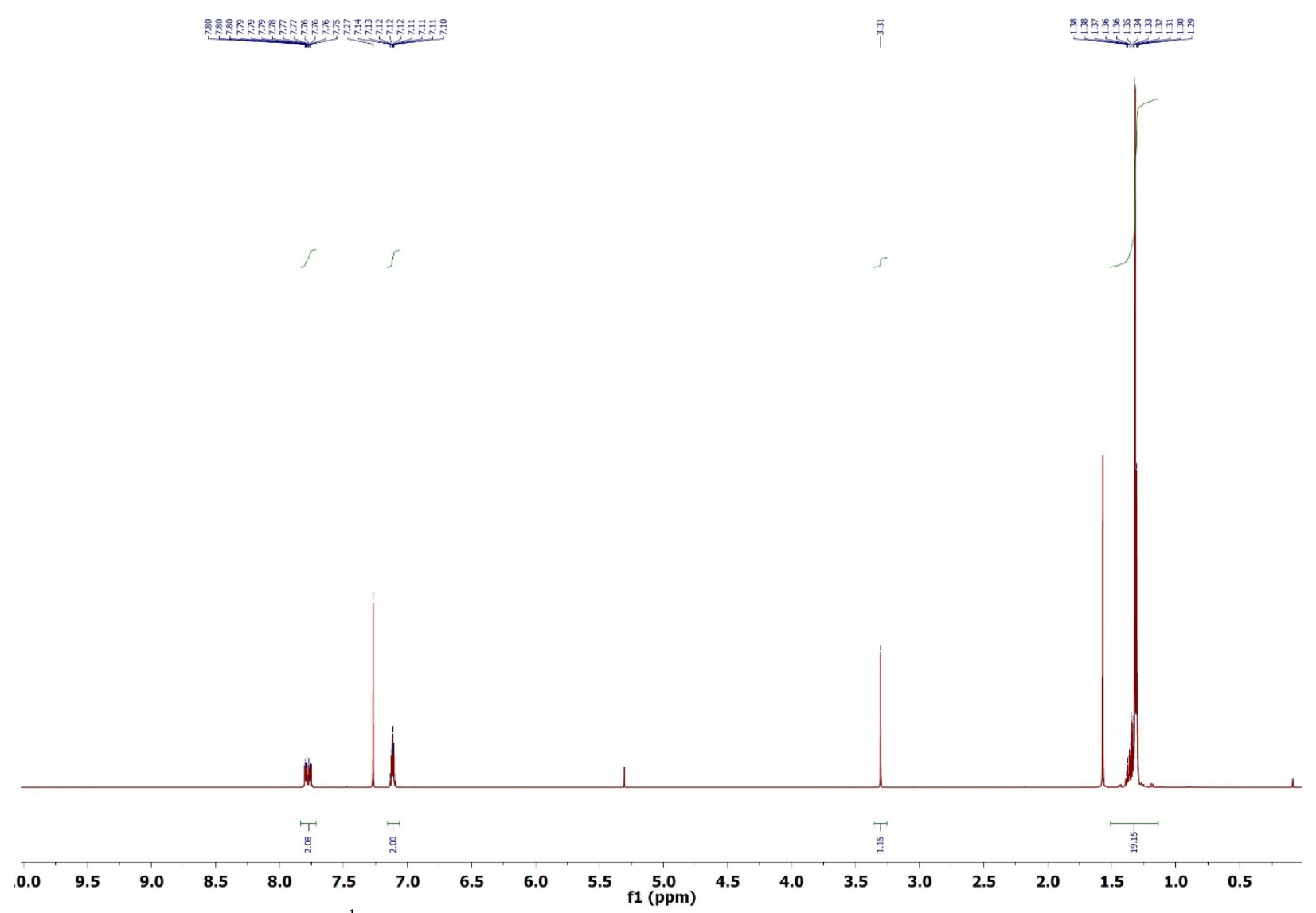

Figure S15. ${ }^{1} \mathrm{H}$ NMR spectrum of compound $\mathbf{1 2 b}$ at $500 \mathrm{MHz}$ in $\mathrm{CDCl}_{3}$. 


\begin{tabular}{|c|c|}
\hline 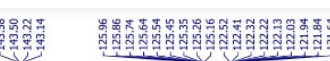 & 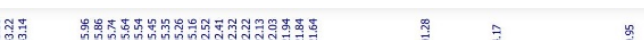 \\
\hline
\end{tabular}

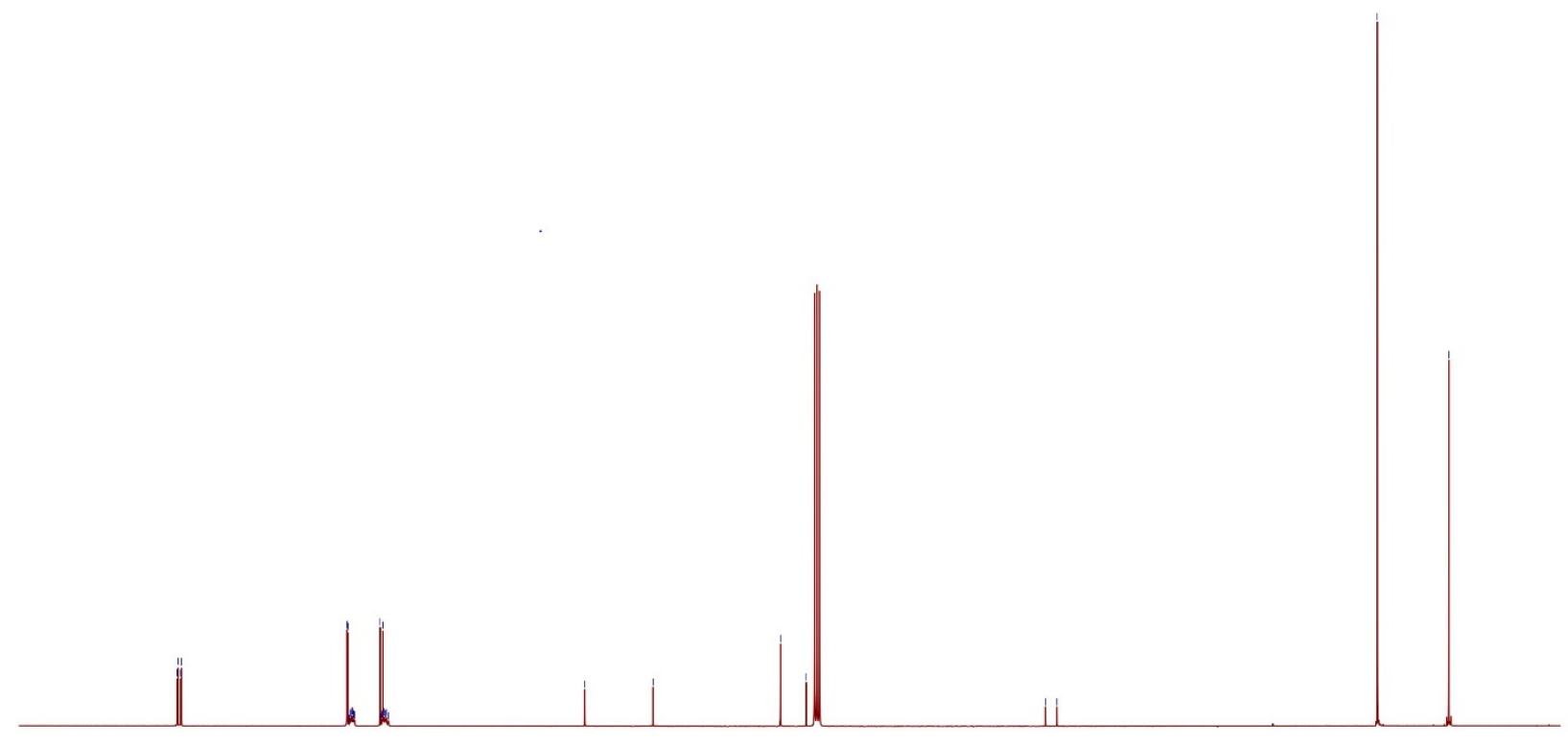

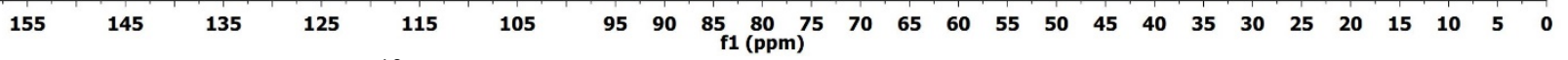

Figure S16. ${ }^{13} \mathrm{C}$ NMR spectrum of compound $\mathbf{1 2 b}$ at $126 \mathrm{MHz}$ in $\mathrm{CDCl}_{3}$.

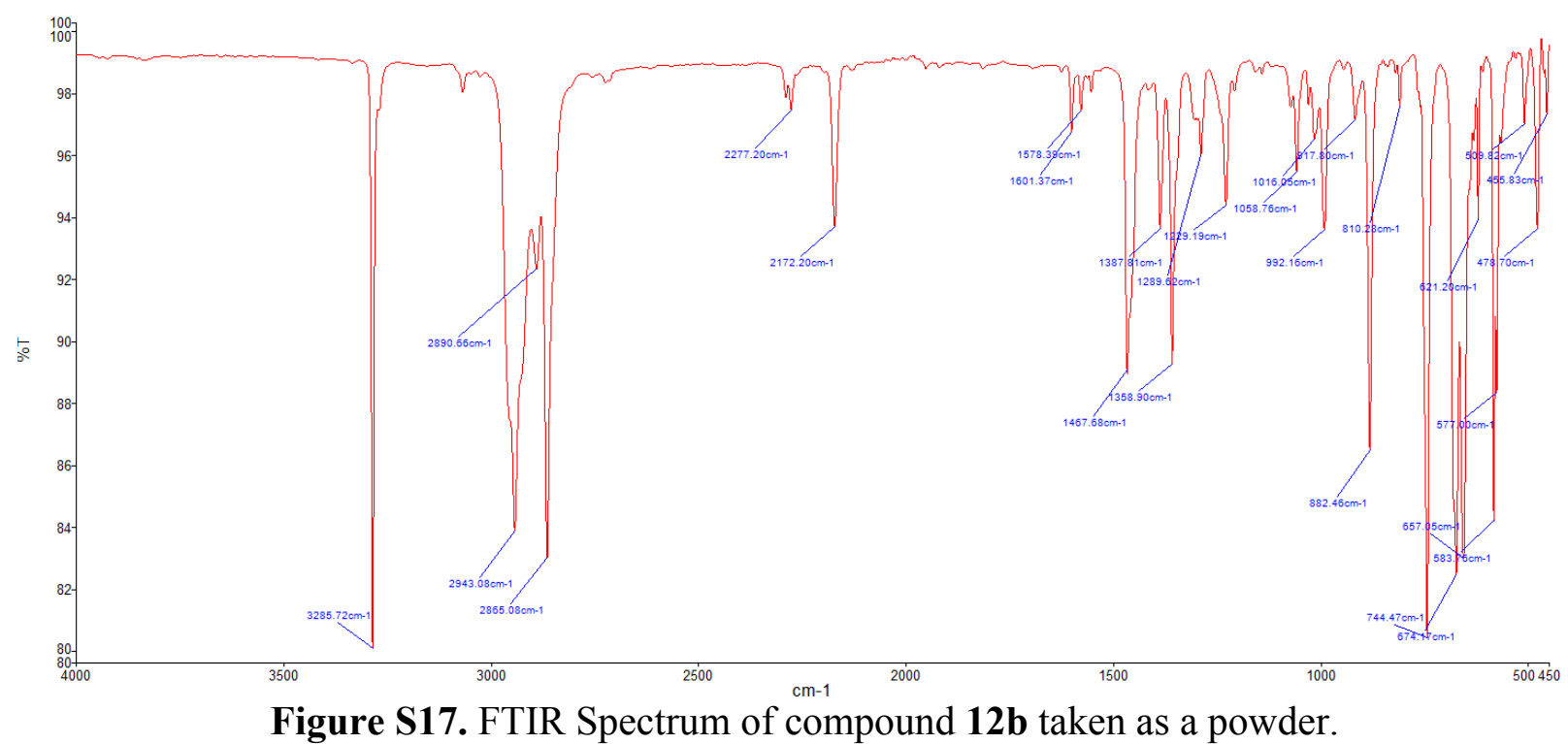



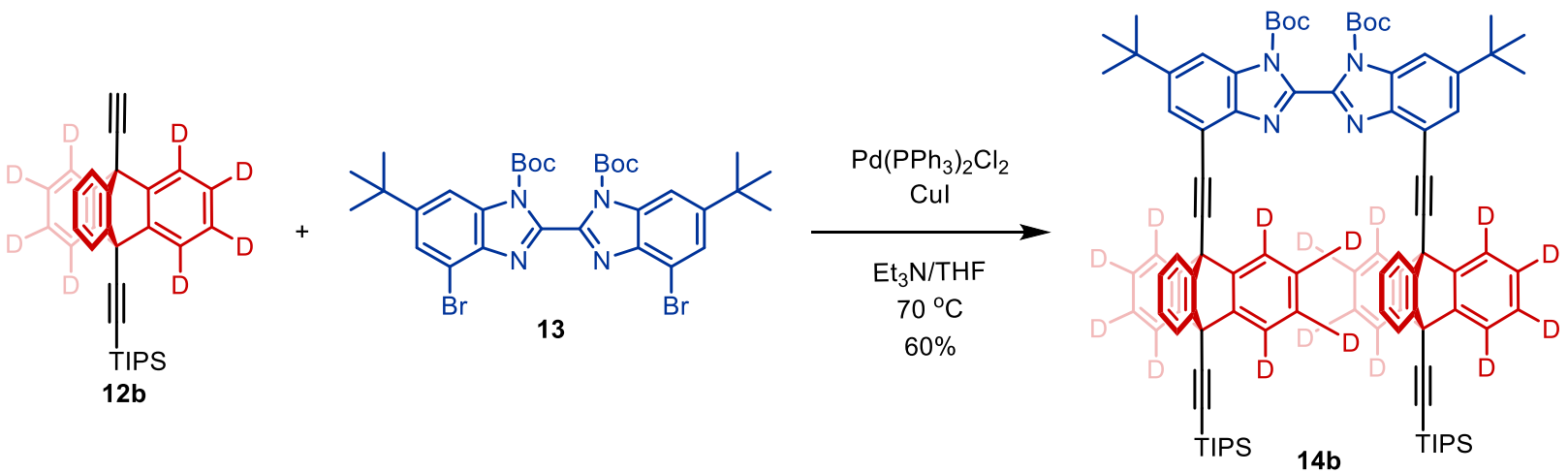

To an argon-flushed solid mixture of $\mathbf{1 2 b}(275 \mathrm{mg}, 0.590 \mathrm{mmol}), \mathbf{1 3}$ (197.6 mg, $0.28 \mathrm{mmol}), \mathrm{CuI}$ $(10.70 \mathrm{mg}, 56.11 \mu \mathrm{mol})$, and $\mathrm{Pd}\left(\mathrm{PPh}_{3}\right)_{2} \mathrm{Cl}_{2}(19.7 \mathrm{mg}, 28.06 \mu \mathrm{mol})$ were added. The flask was then charged with degassed, dry THF $(8 \mathrm{~mL})$ and degassed triethylamine $(8 \mathrm{~mL})$. The reaction mixture was stirred and heated to $70^{\circ} \mathrm{C}$. After $18 \mathrm{~h}$, the solvents were removed from the reaction mixture and the remaining solid was subjected to column chromatography (alumina, hexane $\left./ \mathrm{CH}_{2} \mathrm{Cl}_{2}=9.5: 0.5-9: 1\right)$, giving $\mathbf{1 4 b}$ as a white solid $(248 \mathrm{mg}, 60 \%)$.

Rf 0.6 (alumina, 2:8 $\mathrm{CH}_{2} \mathrm{Cl}_{2}:$ Hexane);

'H NMR (500 MHz, $\left.\mathrm{CDCl}_{3}\right) \delta 8.25(\mathrm{~d}, \mathrm{~J}=1.7 \mathrm{~Hz}, 2 \mathrm{H}), 8.01(\mathrm{dd}, \mathrm{J}=5.6,3.1 \mathrm{~Hz}, 2 \mathrm{H}), 7.93(\mathrm{~d}, \mathrm{~J}=$ $1.7 \mathrm{~Hz}, 2 \mathrm{H}), 7.73(\mathrm{dd}, \mathrm{J}=5.6,3.1 \mathrm{~Hz}, 2 \mathrm{H}), 7.09-6.94(\mathrm{~m}, 2 \mathrm{H}), 1.53(\mathrm{~s}, 16 \mathrm{H}), 1.44(\mathrm{~s}, 16 \mathrm{H})$, $1.28(\mathrm{~d}, \mathrm{~J}=5.3 \mathrm{~Hz}, 42 \mathrm{H})$;

${ }^{1} \mathrm{C}$ NMR $\left(126 \mathrm{MHz}, \mathrm{CDCl}_{3}\right) \delta 149.77,148.02,144.60,143.78,143.70,143.56,143.48,142.20$, $133.13,126.73,126.56,125.88,125.67,125.37,124.39,122.96,122.88,122.60,122.24,122.08$, $121.86,114.98,112.71,101.64,93.79,89.57,88.21,85.80,53.47,53.30,35.61,31.95,29.85$, 28.66, 27.95, 19.01, 11.59;

IR (Film) 2959.33, 2942.81, 2865.17, 2287.75, 2173.48, 1751.44, 1692.74, 1601.62, 1462.37, $1404.16,1352.17,1300.61,1247.94,1233.78,1206.86,1144.19,1121.33,1056,1005.14$, $996.02,974.64,908.85,881.99,843.53,810.17,749.2,735.78,677.87,661.16,621.23,582$, $529.48,500.67,478.9 \mathrm{~cm}^{-1}$;

HRMS (MALDI) Calcd for $\mathrm{C}_{98} \mathrm{H}_{90} \mathrm{D}_{10} \mathrm{~N}_{4} \mathrm{O}_{4} \mathrm{Si}_{2}$ with loss of 2 x Boc $+\mathrm{Na}^{+}$(1297.7606) Found: 1297.7253. 

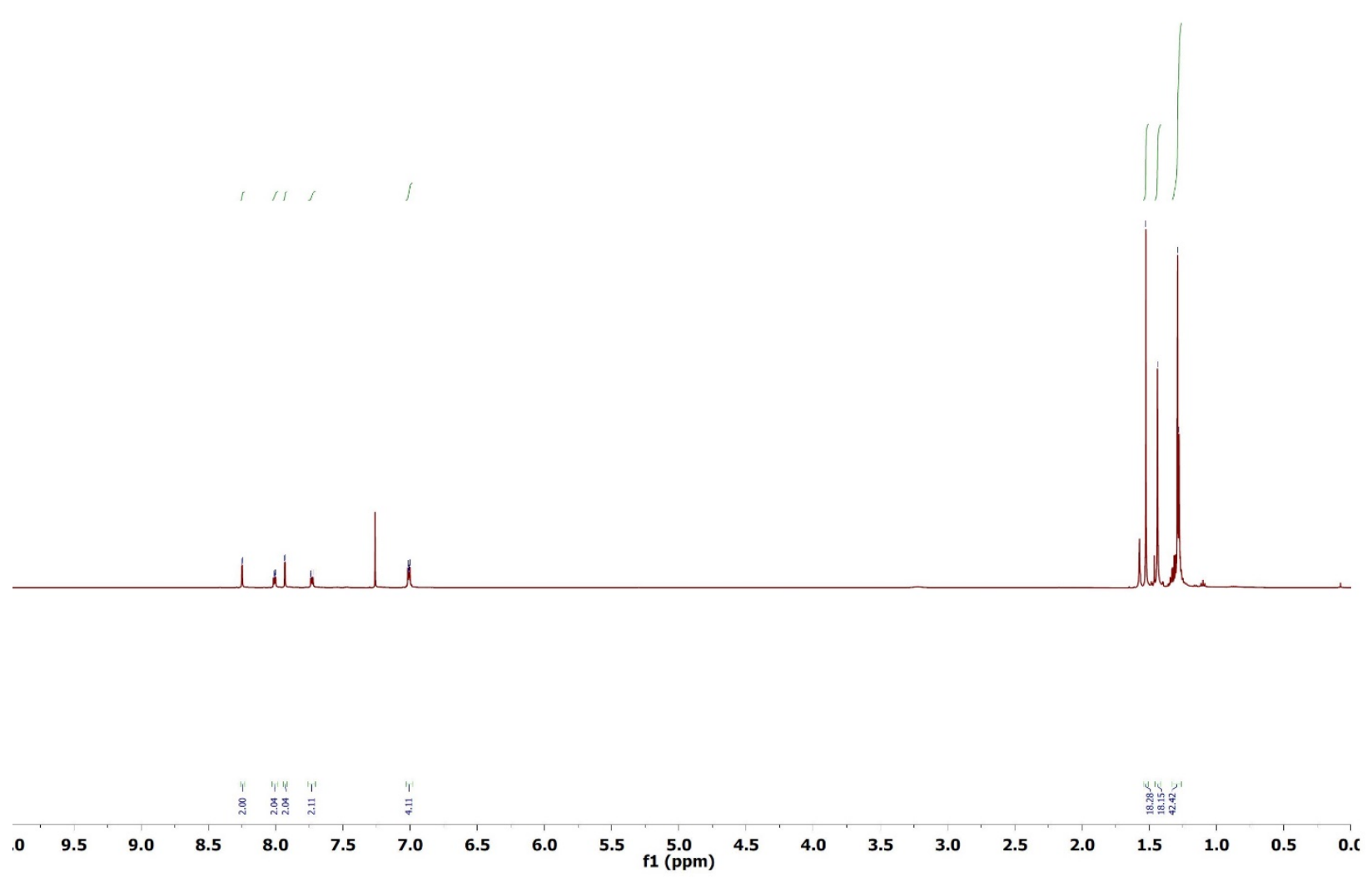

Figure S18. ${ }^{1} \mathrm{H} \mathrm{NMR}$ spectrum of compound $14 \mathbf{b}$ at $500 \mathrm{MHz}$ in $\mathrm{CDCl}_{3}$. 


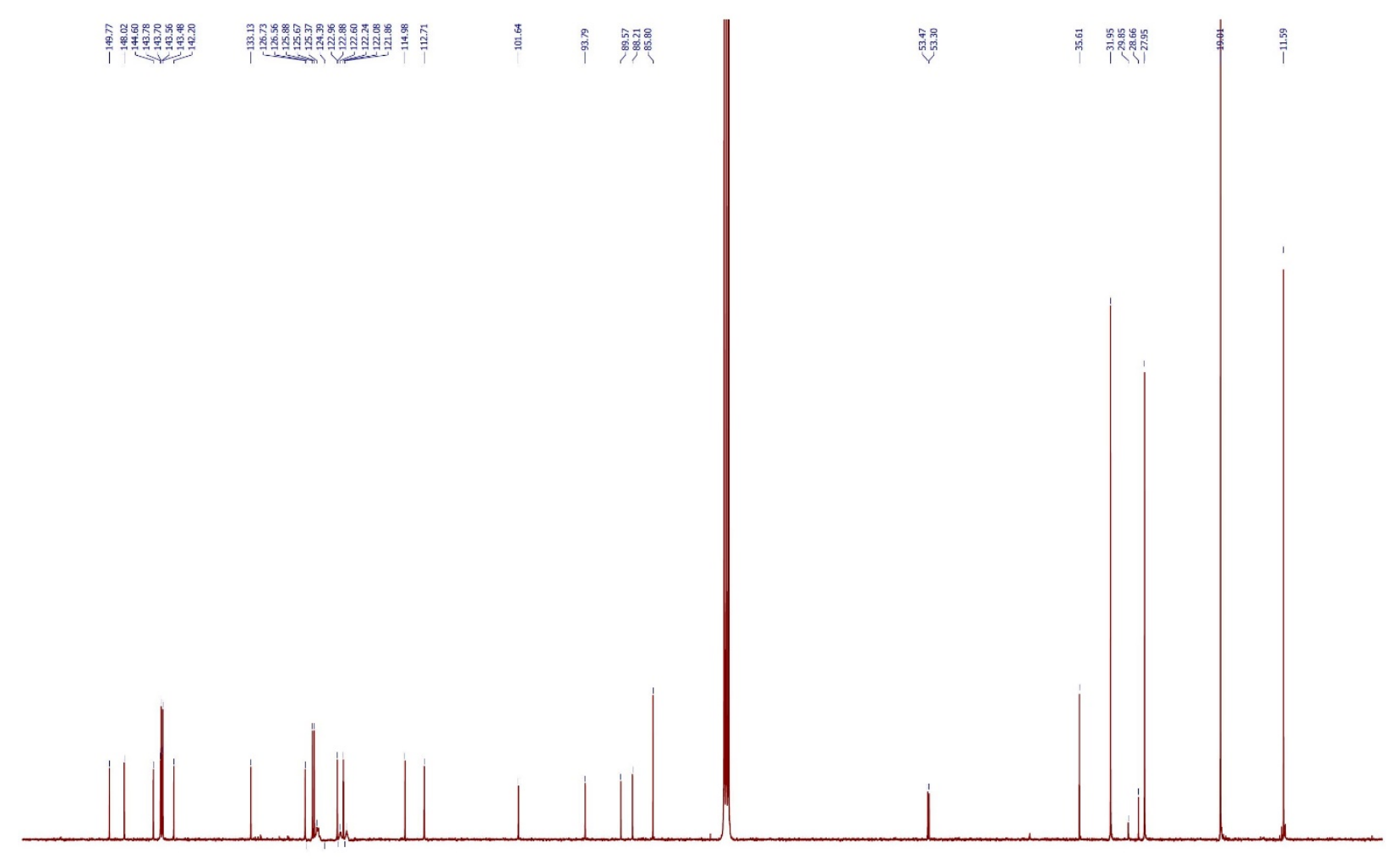

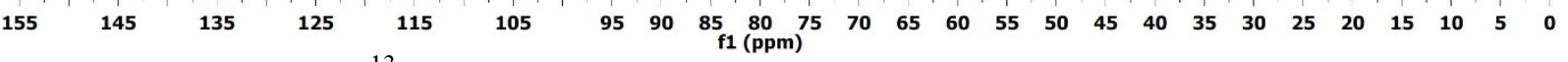

Figure S19. ${ }^{13} \mathrm{C}$ NMR spectrum of compound $14 b$ at $126 \mathrm{MHz}$ in $\mathrm{CDCl}_{3}$.

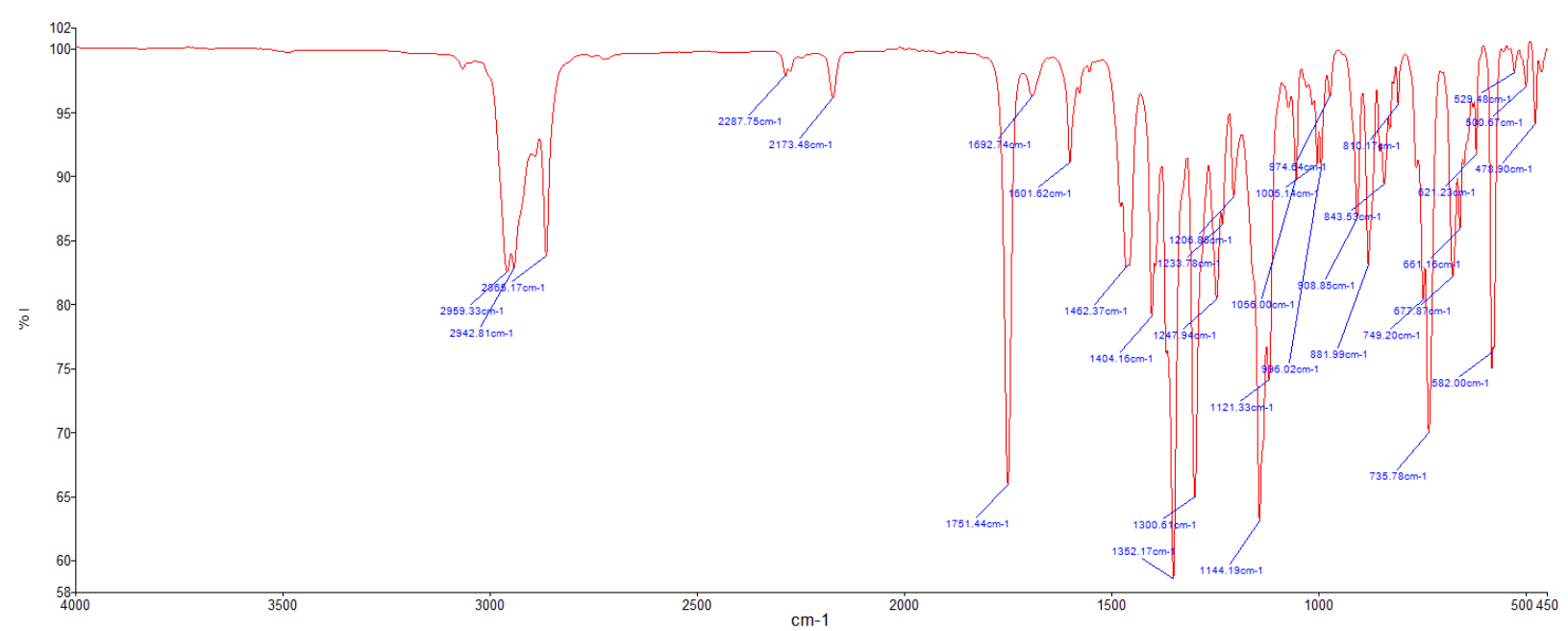

Figure S20 FTIR Spectrum of compound 14b taken as a powder. 


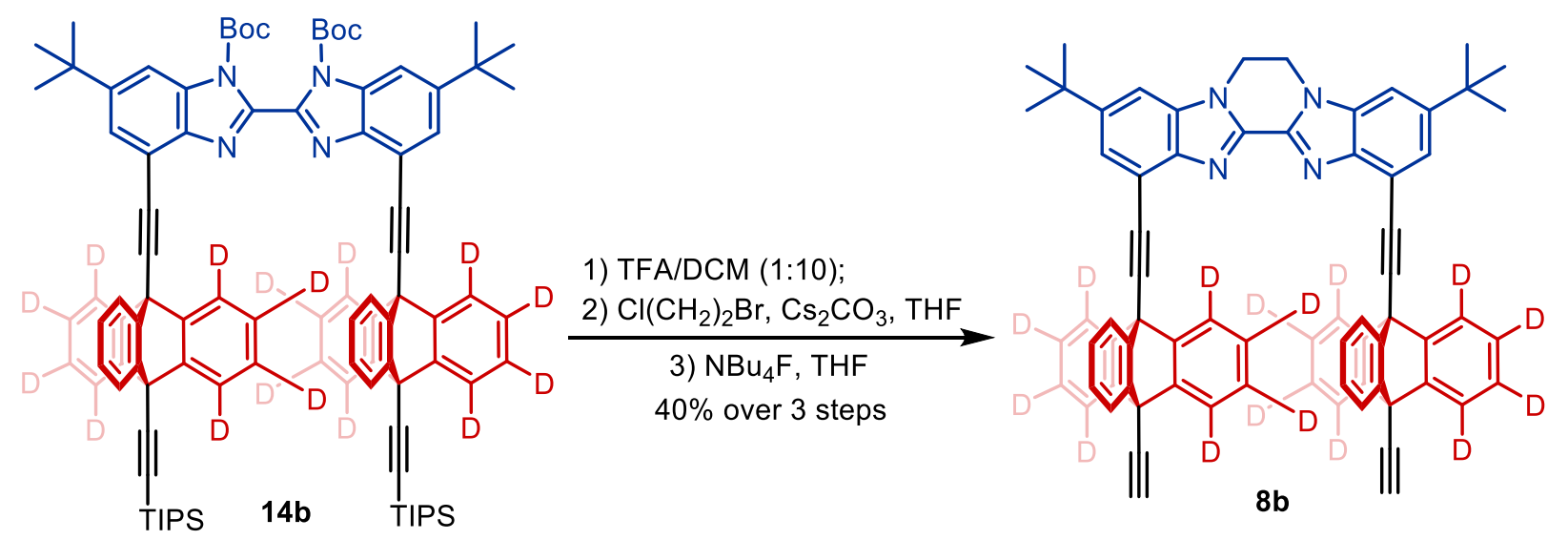

To a solution of $\mathbf{1 4 b}(160 \mathrm{mg}, 0.108 \mathrm{mmol})$ in $\mathrm{CH}_{2} \mathrm{Cl}_{2}(4 \mathrm{~mL})$ under air was added trifluoroacetic acid $(0.45 \mathrm{~mL})$. The reaction mixture was stirred at room temperature for $3 \mathrm{~h}$, after which water, sat. $\mathrm{NaHCO}_{3}$ solution was added until the solution was neutralized. The layers were separated and the aqueous phase was extracted with $\mathrm{CH}_{2} \mathrm{Cl}_{2}$. The combined organic phases were washed with saturated $\mathrm{NaCl}$ solution and dried over $\mathrm{MgSO}_{4}$, and concentrated, affording crude 4,4'bis(triptycen-9-ylethynyl)-6,6'-di-tert-butyl-2,2'-bibenzimidazole- $\boldsymbol{d}_{16}$ as a white solid (138 $\mathrm{mg}$ ), which was used directly in the next step.

Crude 4,4'-bis(triptycen-9-ylethynyl)-6,6'-di-tertbutyl-2,2'-bibenzimidazole- $\boldsymbol{d}_{16}$ (138 mg, 108 $\mu \mathrm{mol})$ was dissolved in THF $(5 \mathrm{~mL})$. To this solution, $\mathrm{Cs}_{2} \mathrm{CO}_{3}(104.5 \mathrm{mg}, 320 \mu \mathrm{mol})$ and excess 1-bromo-2-chloroethane $(3 \mathrm{~mL})$ were added. The reaction mixture was stirred for $17 \mathrm{~h}$ at $60{ }^{\circ} \mathrm{C}$. Water and $\mathrm{CH}_{2} \mathrm{Cl}_{2}$ were added and the layers were separated. The aqueous phase was extracted with $\mathrm{CH}_{2} \mathrm{Cl}_{2}$ and the combined organic phases were washed with sat. $\mathrm{NaCl}$, dried with $\mathrm{MgSO}_{4}$ and concentrated in vacuo. The resulting residue was subjected to column chromatography $\left(\mathrm{SiO}_{2}\right.$, hexane/EtOAc $=7: 3-1: 1$ ) giving $120 \mathrm{mg}$ of white powder.

$120 \mathrm{mg}(0.085 \mathrm{mmol})$ of the resultant compound was added to a $25 \mathrm{~mL}$ round bottom flask and placed under argon. $10 \mathrm{~mL}$ of dry THF was then added to the solution and the mixture was cooled to $-78{ }^{\circ} \mathrm{C}$. Subsequently, $0.2 \mathrm{~mL}(.186 \mathrm{mmol})$ of $1 \mathrm{M}$ TBAF in THF was added to the solution and then the mixture was allowed to warm to $0{ }^{\circ} \mathrm{C}$. The mixture then stirred for 15 minutes before being quenched with a saturated $\mathrm{NH}_{4} \mathrm{Cl}$ solution. The mixture was then extracted 3 times with $20 \mathrm{~mL} \mathrm{CH}_{2} \mathrm{Cl}_{2}$ and the organic phase was dried over $\mathrm{MgSO}_{4}$ and concentrated. The crude mixture was purified with column chromatography $\left(\mathrm{SiO}_{2}\right.$, hexane/EtOAc 1:1) to yield 45 $\mathrm{mg}$ of $\mathbf{8 b}$ as a white, crystalline powder (44\% yield over three steps).

Rf $0.38\left(\mathrm{SiO}_{2}, 1: 2\right.$ EtOAc:Hexane);

'H NMR (600 MHz, $\left.\mathrm{CD}_{2} \mathrm{Cl}_{2}\right) \delta 8.08(\mathrm{dd}, \mathrm{J}=7.5,0.8 \mathrm{~Hz}, 1 \mathrm{H}), 7.89(\mathrm{~d}, \mathrm{~J}=1.7 \mathrm{~Hz}, 1 \mathrm{H}), 7.68(\mathrm{dd}, \mathrm{J}$ $=7.5,0.8 \mathrm{~Hz}, 1 \mathrm{H}), 7.52(\mathrm{~d}, \mathrm{~J}=1.7 \mathrm{~Hz}, 1 \mathrm{H}), 6.98(\mathrm{td}, \mathrm{J}=7.5,1.2 \mathrm{~Hz}, 1 \mathrm{H}), 6.79(\mathrm{td}, \mathrm{J}=7.5,1.2$ $\mathrm{Hz}, 1 \mathrm{H}), 4.77(\mathrm{~s}, 2 \mathrm{H}), 3.28(\mathrm{~s}, 1 \mathrm{H}), 1.54(\mathrm{~s}, 8 \mathrm{H})$;

"C NMR (126 MHz, $\left.\mathrm{CD}_{2} \mathrm{Cl}_{2}\right) \delta 148.78,148.73,144.24,144.20,144.11,144.08,143.50,143.42$, $143.39,142.86,135.04,131.48,129.29,126.58,126.19,126.15,123.24,122.36,121.98,115.11$, $107.64,90.56,88.07,81.44,78.51,52.70,41.53,35.82,32.09,30.25$;

IR (Film) 3282.11, 2964.29, 1602.83, 1466.91, 1417.54, 1376.49, 1355.6, 1337.45, 1323.24, $1266.59,1156.76,1031.03,870,857.1,843.34,811.6,749.54,664.99,621.24,580.88,528.32$, $477.16 \mathrm{~cm}^{-1}$ 
HRMS (APCI) Calcd for $\mathrm{C}_{22} \mathrm{H}_{30} \mathrm{D}_{16} \mathrm{~N}_{4}(\mathrm{M}+1)$ 989.52690, found 989.52785.

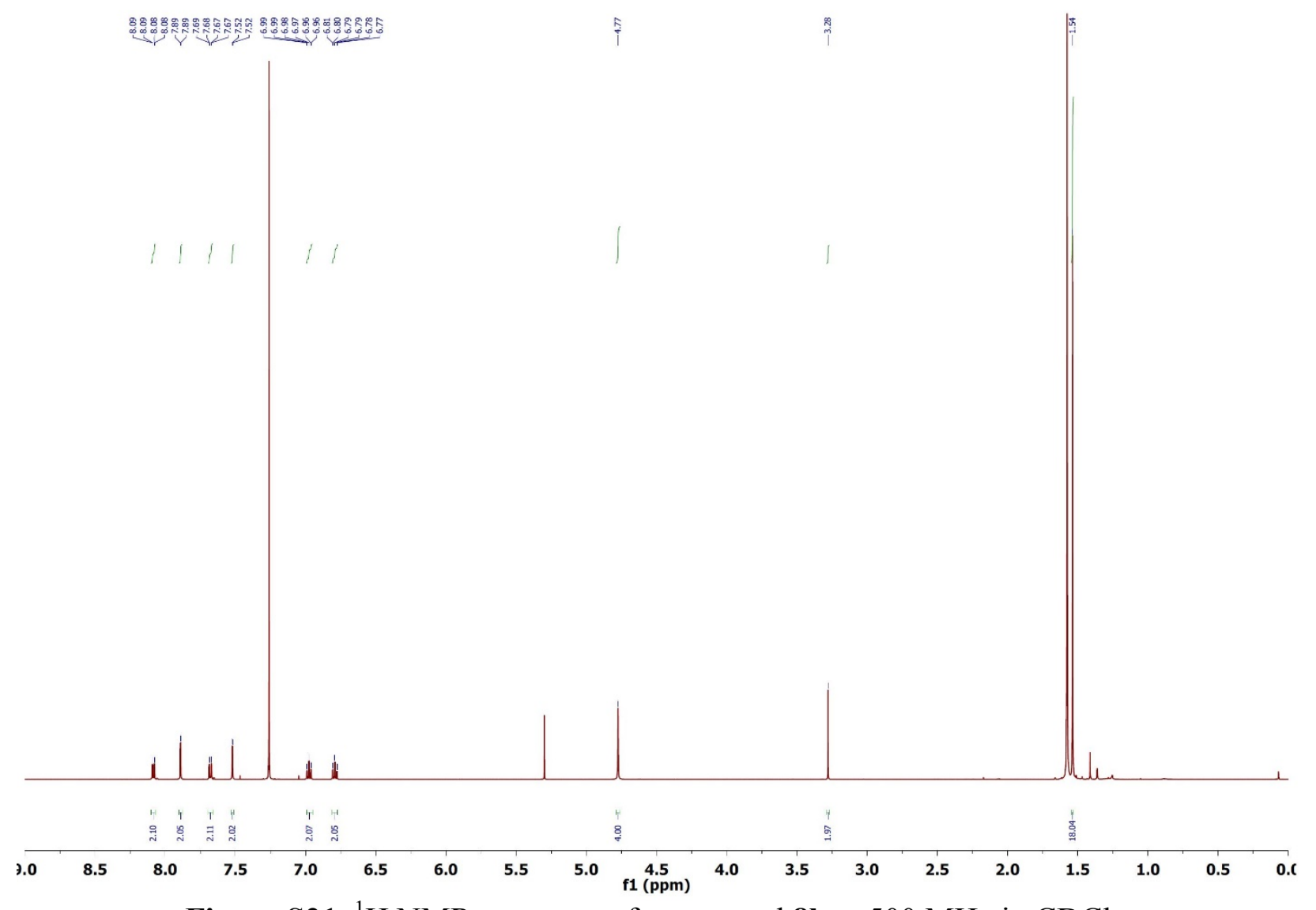

Figure S21. ${ }^{1} \mathrm{H}$ NMR spectrum of compound $\mathbf{8 b}$ at $500 \mathrm{MHz}$ in $\mathrm{CDCl}_{3}$. 


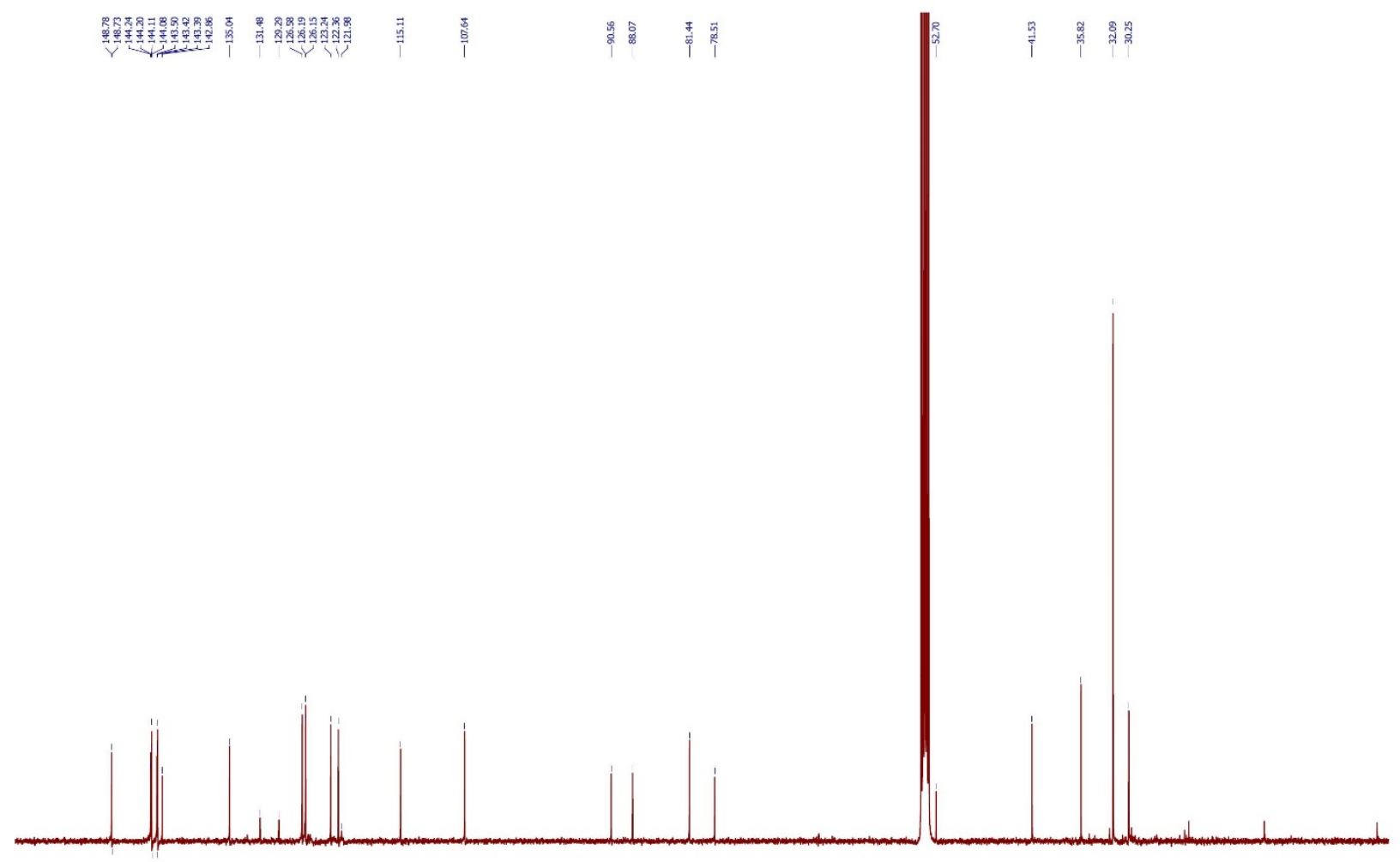

$\begin{array}{llllllllllllllllllllllllllllllllllllllll}155 & 145 & 135 & 125 & 115 & 105 & 95 & 90 & 85 & 80 & 75 & 70 & 65 & 60 & 55 & 50 & 45 & 40 & 35 & 30 & 25 & 20 & 15 & 10 & 5 & 0\end{array}$

Figure S22. ${ }^{13} \mathrm{C}$ NMR spectrum of compound $\mathbf{8 b}$ at $126 \mathrm{MHz}$ in $\mathrm{CD}_{2} \mathrm{Cl}_{2}$.

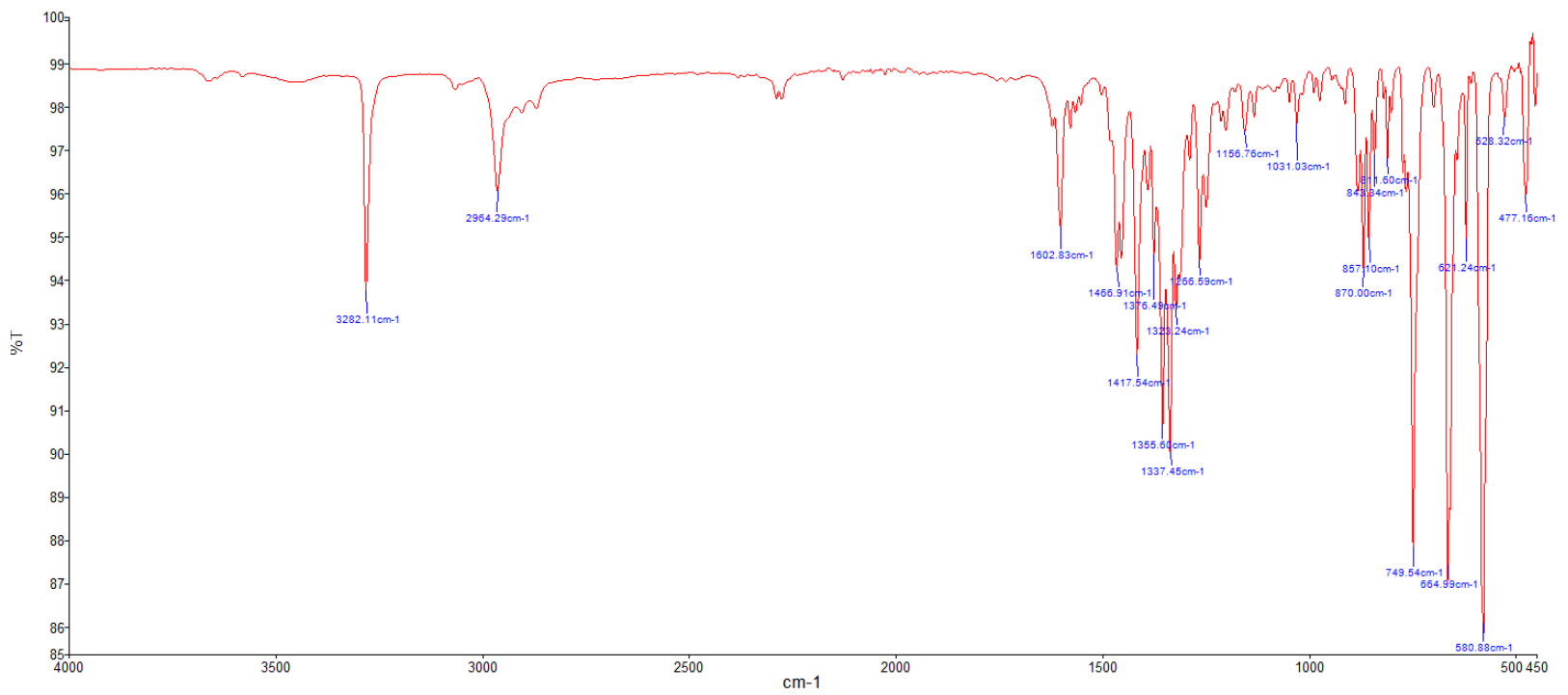

Figure S23. FTIR Spectrum of compound $\mathbf{8 b}$ taken as a powder. 

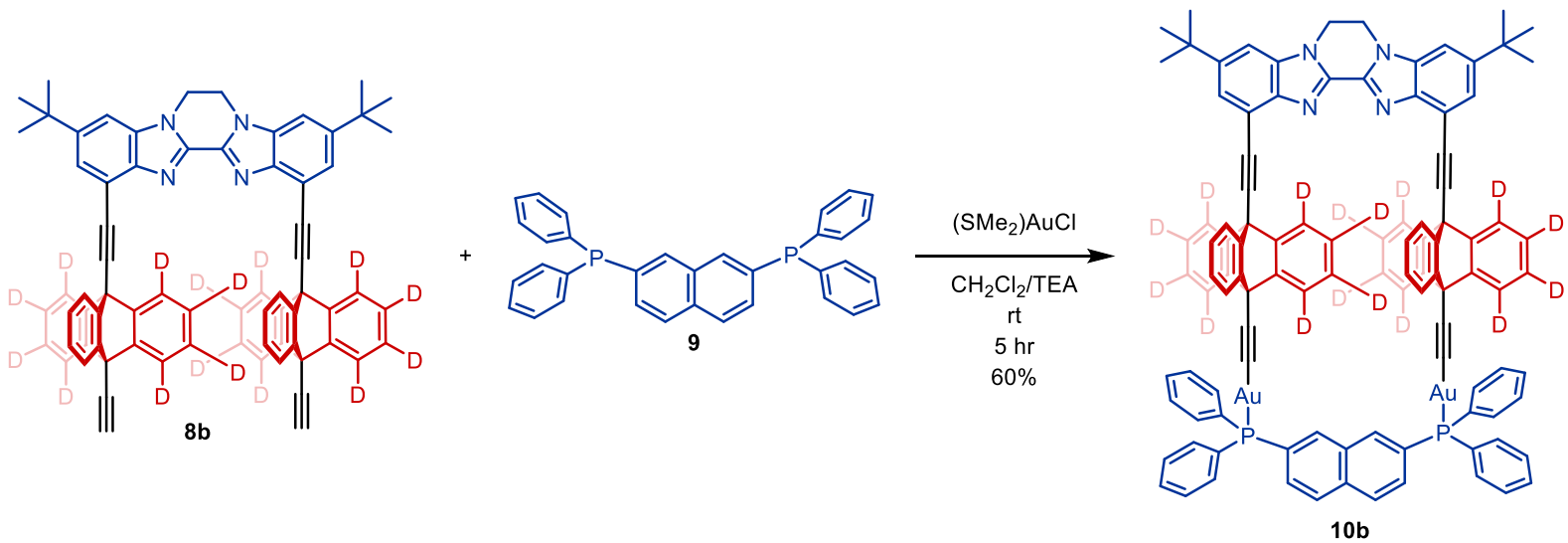

$\mathbf{8 b}(10 \mathrm{mg}, 0.010 \mathrm{mmol})$ was dissolved in $5 \mathrm{~mL}$ of $\mathrm{CH}_{2} \mathrm{Cl}_{2}$ and added to a $25 \mathrm{~mL}$ round bottomed flask. $\left(\mathrm{SMe}_{2}\right) \mathrm{AuCl}(6.05 \mathrm{mg}, 0.020 \mathrm{mmol})$ dissolved in $5 \mathrm{~mL} \mathrm{CH} \mathrm{Cl}_{2}$ was then added followed by 1 drop of triethylamine. This mixture was stirred for 15 min to allow complexation to occur, which can be convenient monitored by the disappearance of $\mathbf{8 b}$ on TLC. After this, 9 (5.10 mg, $0.01 \mathrm{mmol}$ ) dissolved in $5 \mathrm{~mL}$ of $\mathrm{CH}_{2} \mathrm{Cl}_{2}$ was added dropwise and the final mixture was stirred for $3 \mathrm{hrs}$. Additional 9 could be titrated into the mixture if complete conversion of $\mathbf{8 b}$ into $\mathbf{1 0 b}$ did not proceed efficiently. After completion of the reaction, the mixture was run through a small silica plug and rinsed multiple times with $\mathrm{CH}_{2} \mathrm{Cl}_{2}$. This mixture was then concentrated in vacuo to yield a crude yellow colored paste. This paste was then dissolved in $3 \mathrm{~mL} \mathrm{CH}_{2} \mathrm{Cl}_{2}$ and then $5 \mathrm{~mL}$ of hexane and $1 \mathrm{~mL}$ of $\mathrm{MeOH}$ was added to crashed $\mathbf{1 0 b}$ out of solution. This heterogeneous mixture was then centrifuged and the solvent mixture was removed. This powder was then washed with $3 \mathrm{~mL}$ of $\mathrm{CH}_{2} \mathrm{Cl}_{2}$ and $6 \mathrm{~mL}$ of hexane 3 more times with centrifugation between each step. After completion of these purifications, the white powder was dried to yield $11.6 \mathrm{mg}$ of $\mathbf{1 0 b}$ (60\% yield).

\section{Rf 0.25 ( $\mathrm{SiO}_{2}, 4: 1 \mathrm{CH}_{2} \mathrm{Cl}_{2}:$ Hexane);}

$\mathrm{mp} 420^{\circ} \mathrm{C}$ (decomposition);

'H NMR (500 MHz, $\left.\mathrm{CD}_{2} \mathrm{Cl}_{2}\right) \delta 9.23(\mathrm{~d}, \mathrm{~J}=17.2 \mathrm{~Hz}, 2 \mathrm{H}), 8.06(\mathrm{dd}, \mathrm{J}=7.5,0.7 \mathrm{~Hz}, 2 \mathrm{H}), 8.01(\mathrm{~d}, \mathrm{~J}$ $=7.0 \mathrm{~Hz}, 2 \mathrm{H}), 7.92(\mathrm{~d}, \mathrm{~J}=1.7 \mathrm{~Hz}, 2 \mathrm{H}), 7.88(\mathrm{dd}, \mathrm{J}=7.5,0.8 \mathrm{~Hz}, 2 \mathrm{H}), 7.79-7.67(\mathrm{~m}, 2 \mathrm{H}), 7.58$ (dddd, $\mathrm{J}=11.2,6.5,5.6,2.0 \mathrm{~Hz}, 1 \mathrm{H}), 7.47(\mathrm{td}, \mathrm{J}=8.4,1.5 \mathrm{~Hz}, 1 \mathrm{H}), 6.87(\mathrm{td}, \mathrm{J}=7.4,1.2 \mathrm{~Hz}$, $1 \mathrm{H}), 6.60(\mathrm{td}, \mathrm{J}=7.4,1.2 \mathrm{~Hz}, 1 \mathrm{H}), 4.80(\mathrm{~s}, 1 \mathrm{H}), 1.55(\mathrm{~s}, 1 \mathrm{H})$

IR (Film) 2956.95, 1601, 1454.78, 1436.33, 1356.86, 1249.43, 1156.54, 1098.37, 1027.36, 998.52, 915.56, 880.56, 844.93, 808.54, 745.26, 692.18, 659.71, 621.48, 583.03, 565.71, 537.65, $493.64,476.48 \mathrm{~cm}^{-1}$;

HRMS (MALDI) Calcd for $\mathrm{C}_{106} \mathrm{H}_{60} \mathrm{D}_{16} \mathrm{Au}_{2} \mathrm{~N}_{4} \mathrm{P}_{2}[\mathrm{M}+\mathrm{Na}]^{+} 1899.5778$, found 1899.4804 . 


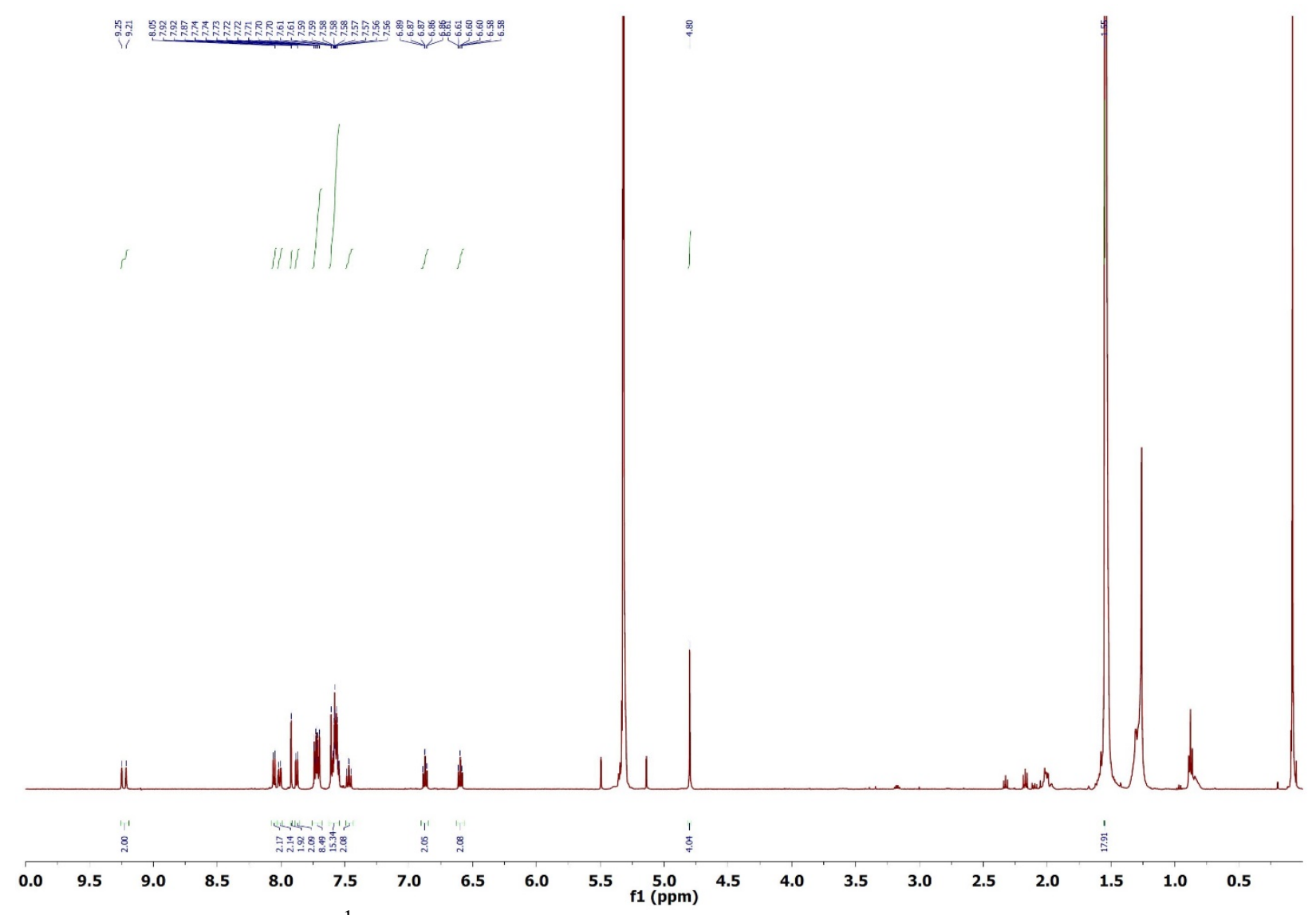

Figure S24. ${ }^{1} \mathrm{H} \mathrm{NMR}$ spectrum of compound $\mathbf{1 0 b}$ at $500 \mathrm{MHz}$ in $\mathrm{CD}_{2} \mathrm{Cl}_{2}$.

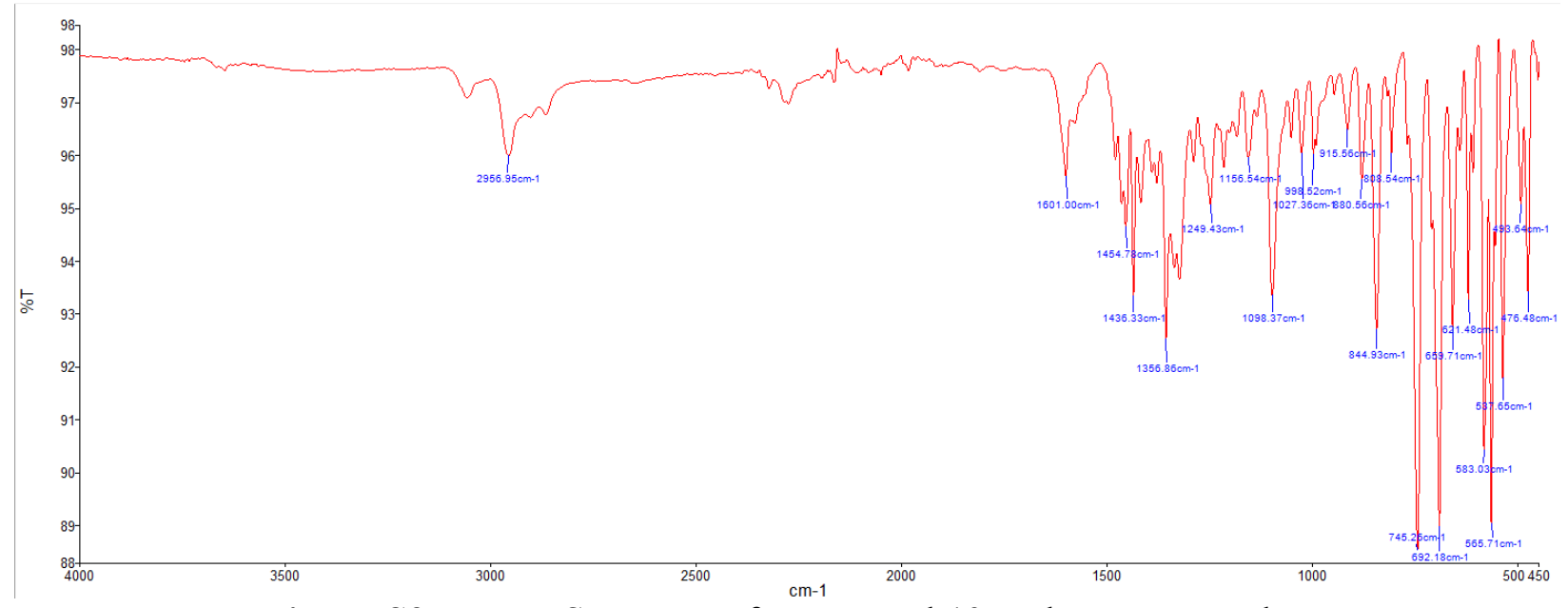

Figure S25. FTIR Spectrum of compound $\mathbf{1 0 b}$ taken as a powder.

Section C. Variable Temperature ${ }^{1}$ H NMR 

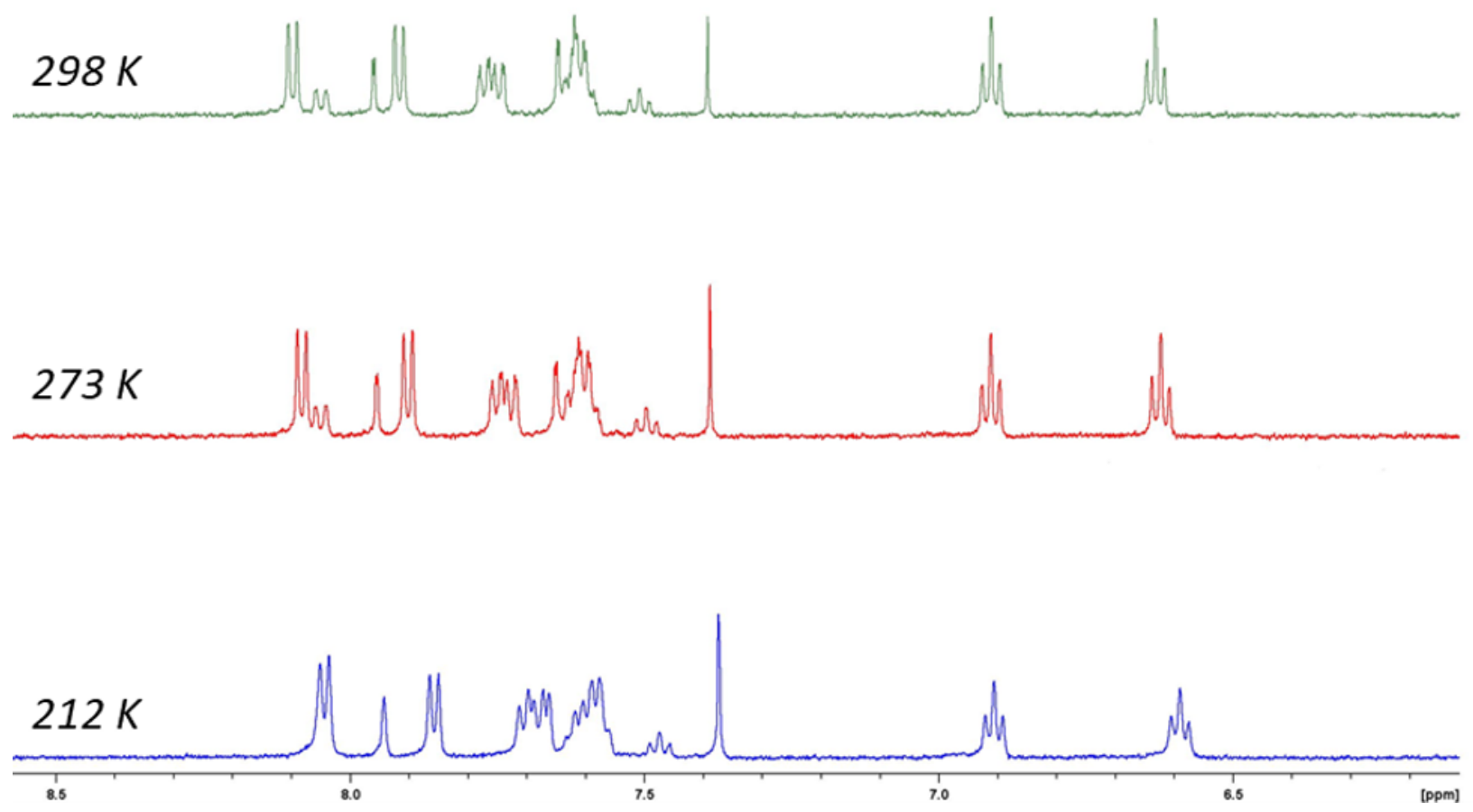

Figure S26. Variable-temperature 1H spectra of MSG 10a at temperatures ranging from 298 to $212 \mathrm{~K}$

\section{Section D. Micro Electron-Diffraction}

\section{Sample Preparation for Electron Diffraction}

Samples were prepared using Quantifoil TEM grids. To prepare sample grids, a new TEM grid was placed in a vial with the sample as a dry powder and gently shaken. TEM grids were then placed in a standard single-tilt TEM holder at room temperature.

\section{Instrument Parameters}

Data was acquired on an FEI Tecnai TF-30 electron microscope operating at ambient temperature with and operating voltage of $300 \mathrm{KeV}$, corresponding to a wavelength of $0.0196 \AA$. Screening of the TEM grids for micro crystals was done by operating the microscope in over focused diffraction mode to minimize diffraction and hysteresis between screening and diffraction operational modes.

\section{Electron Diffraction Data Collection Procedure}

Electron diffraction data was collected using a TVIPS TemCam-XF416 CMOS 4k x 4k camera. Images were collected in a movie format as crystals were continuously rotated in the electron beam. Typical data collection was performed using a constant tilt rate of $0.3 \%$ between the 
minimum and maximum tilt ranges of $-72^{\circ}$ to $+72^{\circ}$, respectively. During continuous rotation the camera integrated frames continuously at a rate of 3 seconds per frame. The dose rate was calibrated to $<0.03 \mathrm{e}^{-} / \AA^{2}$ s. Crystals selected for data collection were isolated by a selected area aperture to reduce the background noise contributions and calibrated to eucentric height to stay in the aperture over the entire tilt range.

\section{Crystallographic Data Processing}

All diffraction data were processed using the XDS suite of programs [W. Kabsch, Acta Cryst. D66, 125-132 (2010)]. All structures were solved ab initio using direct methods in SHELXT [G.M. Sheldrick, Acta Cryst. A71, 3-8 (2015)] or SHELXD [G.M. Sheldrick, Acta Cryst. D58, 1772-1779 (2002)] and refined with SHELXL [G.M. Sheldrick, Acta Cryst. C71, 38 (2015).] using ShelXle [G.M. Sheldrick J. Appl. Cryst., 44, (2011) 1281-1284].

\begin{tabular}{|l|l|}
\hline Empirical formula & $\mathrm{C}_{106} \mathrm{H}_{76} \mathrm{~N}_{4} \mathrm{P}_{2} \mathrm{Au}_{2}$ \\
\hline Formula weight $(\mathrm{g} / \mathrm{mol})$ & 1861.68 \\
\hline Crystal system & Monoclinic \\
\hline Space group & $\mathrm{P} 2(1) / \mathrm{n}(14)$ \\
\hline Point group & 2 \\
\hline Laue symmetry & $2 / \mathrm{m}$ \\
\hline Temperature $(\mathrm{K})$ & 293 \\
\hline Unit cell lengths a, b, c $(\AA)$ & $15.240(5), 30.41(1), 23.080(16)$ \\
\hline Unit cell angles $\alpha, \beta, \gamma\left({ }^{\circ}\right)$ & $90.000,88.04(6), 90.000$ \\
\hline Unit cell volume $\left(\AA^{3}\right)$ & 10690 \\
\hline $\mathrm{F}(000)$ & 3711.2 \\
\hline$Z$ & 4 \\
\hline Density $($ calculated $)\left(\mathrm{g} / \mathrm{cm}^{3}\right)$ & 1.157 \\
\hline Radiation source, wavelength $(\AA)$ & electron, 0.01969 \\
\hline Resolution $(\AA)$ & 1.10 \\
\hline Measured reflections & 27672 \\
\hline Unique reflections & 6521 \\
\hline Reflections with $I>2 \sigma(I)$ & 4262 \\
\hline Completeness & $77.6 \%(3$ merged datasets $)$ \\
\hline$I / \sigma$ & 4.68 \\
\hline$\Theta_{\text {max }}, \Theta_{\min }\left({ }^{\circ}\right)$ & $0.513,0.071$ \\
\hline Index ranges & $-13 \leq h \leq 13,-27 \leq k \leq 27$, \\
& $-18 \leq l \leq 18$ \\
\hline Refinement method & Full-matrix least-squares on $\mathrm{F}^{2}$ \\
\hline $\mathrm{H}-$-atom treatment & $\mathrm{H}$-atom parameters constrained \\
\hline$R\left[F^{2}>2 \sigma\left(F^{2}\right)\right]$ & 0.131 \\
\hline$w R\left(F^{2}\right)$ & 0.369 \\
\hline Goodness-of-fit on $\mathrm{F}^{2}$ & 1.120 \\
\hline$\Delta \rho_{\text {max }}, \Delta \rho_{\text {min }}\left(\mathrm{e} / \AA^{3}\right)$ & $0.12,-0.15$ \\
\hline & \\
\hline
\end{tabular}




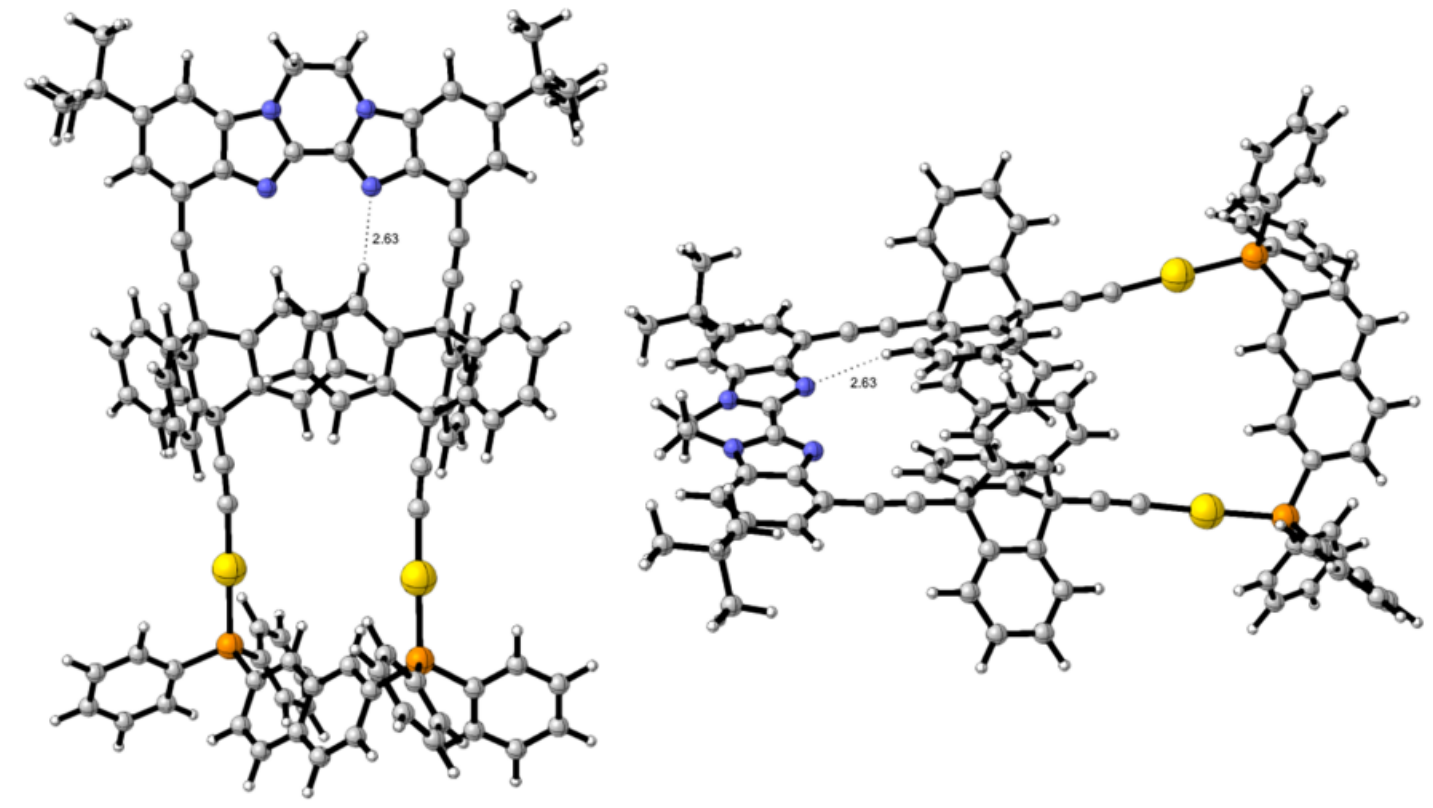

Figure S27. Key hydrogen-bonding interaction in the crystal structure may stabilize the transition state for gearing.

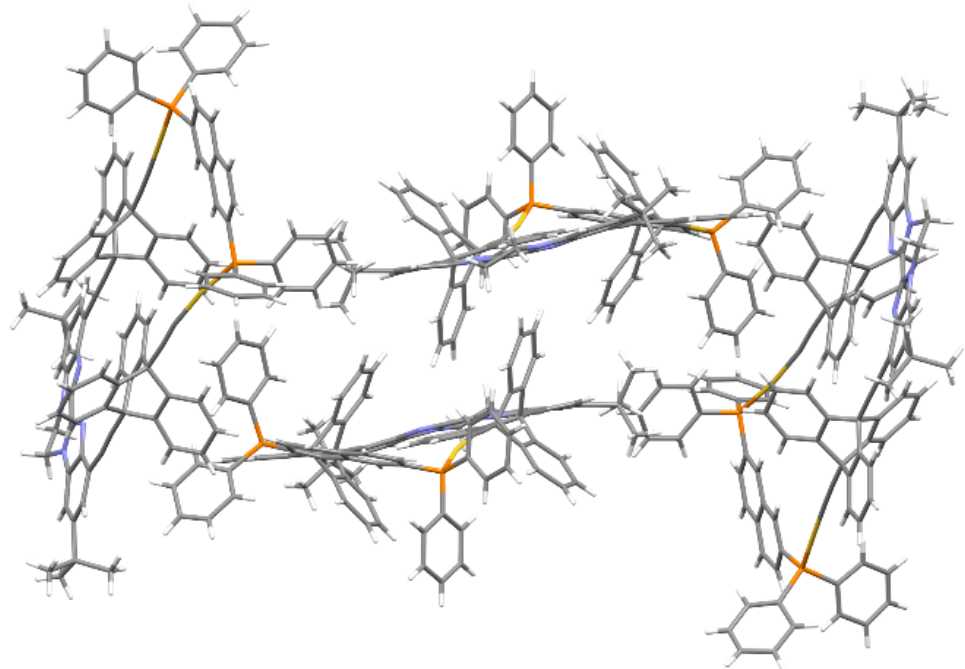

Figure S28. Image detailing the packing arrangement of 10a.

Section E. Computational Methods

Molecular Dynamics Simulations 
Molecular dynamics simulations were performed using the GPU code $\left(\right.$ pmemd $^{3}$ of the AMBER 16 package. ${ }^{4}$ Parameters for the studied gear systems were generated within the antechamber module using the general AMBER force field (gaff). ${ }^{5}$ Parameters involving the $\mathrm{Au}^{2+}$ ions were generated with the Metal Center Parameter Builder (MCPB.py) ${ }^{6,7}$ using optimization and frequency calculations performed in Gaussian $09^{8}$ at the B3LYP ${ }^{9,10} / 6-31 \mathrm{G}(\mathrm{d})$ level, with the LANL2DZ basis set and pseudopotential being used for the $\mathrm{Au}^{2+}$ ions. Partial charges were set to fit the electrostatic potential generated at the HF/6-31G(d) level by the RESP model, ${ }^{11}$ with the LANL2DZ basis set and effective core potential ${ }^{12}$ again being used for the $\mathrm{Au}^{2+}$ ions. These partial charges were calculated according to the Merz-Singh-Kollman scheme $^{13,14}$ using Gaussian 09. Each molecular gear was immersed in a pre-equilibrated truncated octahedral box with a $15 \AA$ buffer of DCM solvent molecules using the leap module. All subsequent calculations were done using the widely tested Stony Brook modification of the Amber14 force field $(f f 14 s b) .{ }^{15}$ DCM molecules were treated with the SHAKE algorithm such that the angle between the hydrogen atoms was kept fixed. Long-range electrostatic effects were modeled using the particle-mesh-Ewald method. ${ }^{16}$ An $8 \AA$ cutoff was applied to Lennard-Jones and electrostatic interactions. First, a geometry optimization was performed on each system to minimize the positions of solvent molecules while imposing positional restraints on the molecular gear using a harmonic potential with a force constant of $2 \mathrm{kcal} \cdot \mathrm{mol}^{-1} \cdot \AA^{-2}$. Second, each system was gently and continuously heated over $1 \mathrm{~ns}$ from $0 \mathrm{~K}$ to $207 \mathrm{~K}, 247 \mathrm{~K}$ and $300 \mathrm{~K}$, respectively, under constant-volume and periodic-boundary conditions. Harmonic restraints of 2 $\mathrm{kcal} \cdot \mathrm{mol}^{-1}$ were applied to the molecular gear and the Andersen equilibration scheme was used to control and equalize the temperature. The time step was kept at $1 \mathrm{fs}$ during the heating stages, allowing potential inhomogeneities to self-adjust. Third, each system was then equilibrated for a total of $4 \mathrm{~ns}$ at constant pressure of 1 atm with a Berendson barostat with a 2 fs time step; harmonic restraints of $2 \mathrm{kcal} \cdot \mathrm{mol}^{-1}$ were applied for the first $2 \mathrm{~ns}$ and harmonic restraints of 1 $\mathrm{kcal} \cdot \mathrm{mol}^{-1}$ were applied for the second $2 \mathrm{~ns}$. Finally, production trajectories without harmonic restraints were run for an additional $1 \mu$ s under the same simulation conditions.

\section{Metadynamics}

Metadynamics simulations ${ }^{17,18}$ were performed using NAMD v2.13 ${ }^{19}$ parallel, object-oriented molecular dynamics code. AMBER coordinate and parameter PARM files were used as an input for metadynamics simulations. Collective variables used to construct the free-energy surface ${ }^{18}$ were chosen to be the dihedral angles that define each triptycene in the molecular gear. The dihedral angle was defined as an angle between the plane of bibenzimidazole stator and the plane of triptycene blade, and was constrained to change in the $-180^{\circ}$ to $180^{\circ}$ range. Well-tempered metadynamics $^{20}$ in conjunction with multiple-walker algorithm was used to accelerate convergence of the free energy landscape. Collective variable space was sampled to a modified temperature $\mathrm{T}+\Delta \mathrm{T}$, where $\mathrm{T}$ was $300 \mathrm{~K}$ and $\Delta \mathrm{T}$ was $100 \mathrm{~K}$. The Langevin thermostat ${ }^{21}$ controlled the temperature at $300 \mathrm{~K}$ and Langevin barostat kept at the pressure at $1 \mathrm{~atm}$ under 
periodic-boundary conditions. The system was first minimized for 500 steps and equilibrated for $10 \mathrm{~ns}$ to eliminate bad initial contacts. The velocities were then initialized to the desired target temperature, and the simulation was run for 2500000 steps per walker utilizing 10 walkers in total $(500 \mathrm{~ns})$. Free energies were calculated and the potential of mean force plot as a function of collective variables was generated.

\section{Density Functional Theory (NMR Calculations)}

DFT NMR calculations of ground state structure were carried out using Gaussian16. Single point NMR calculations ( $\mathrm{nmr}=$ giao) with implicit solvent (PCM model) were performed using the B3LYP-D3 functional and the 6-311G(d,p) basis set for nonmetal atoms and the SDD basis set with effective core potential (ECP) for Au. Isotropic shift values were extracted for all hydrogen atoms on intermeshed triptycene gears and scaled accordingly using TMS as a reference. (Table S1).

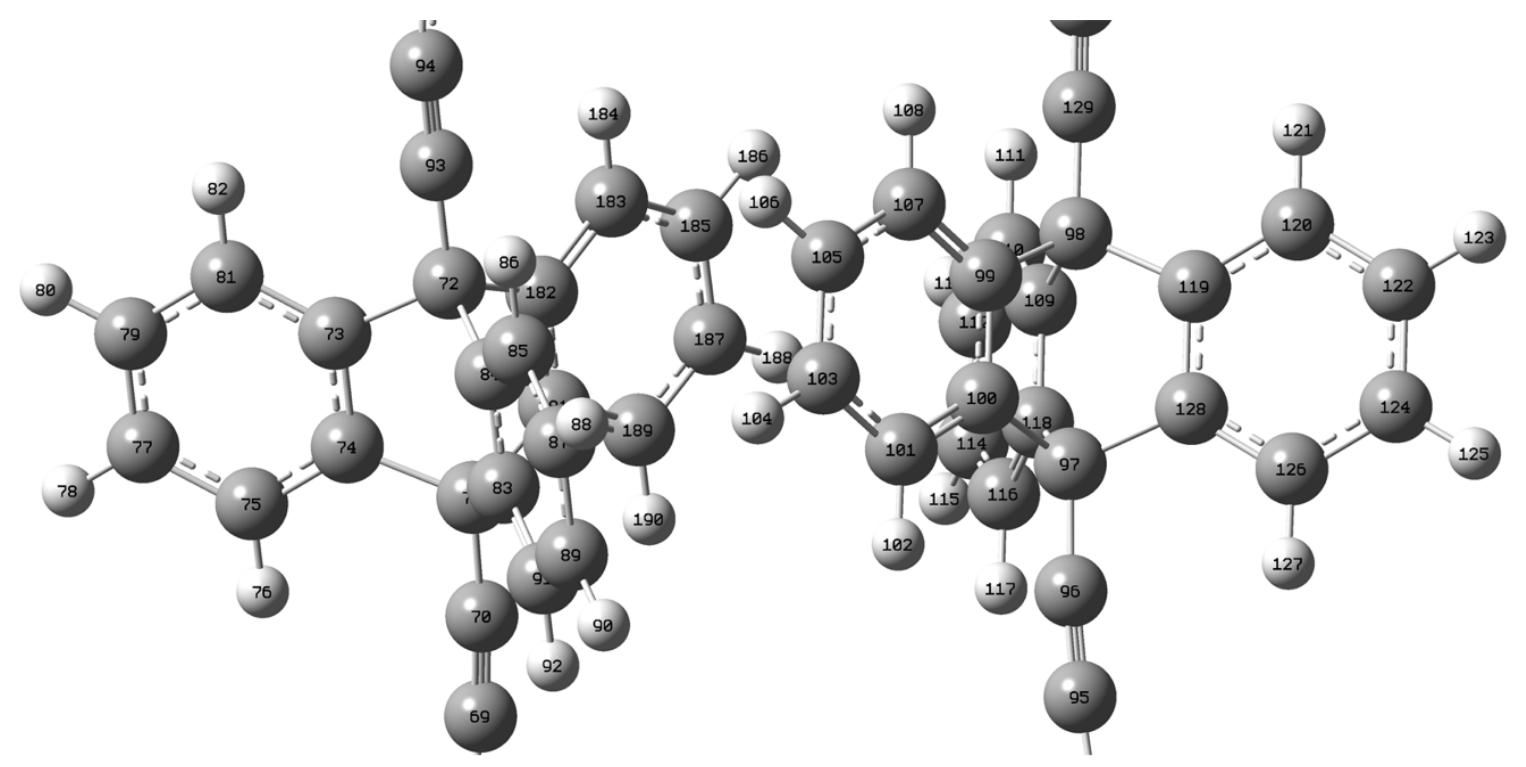

Figure S29. Hydrogen and carbon atom ID numbers on triptycene gears from DFT NMR calculations.

Table S1. Hydrogen atom ID numbers and isotropic shift values (ppm) from DFT NMR calculations of triptycene spur gears. Isotropic shift values were scaled using TMS as a reference. Several hydrogen atom pairs are highlighted in green (H80 and H186) and yellow (H82 and H184) for comparison. 
Triptycene 1

$\begin{array}{ccccc}\text { ID } & \text { Atom type } & \text { Isotropic (ppm) } & \text { TMS Shielding } & \text { Scaled (ppm) } \\ 76 & \mathrm{H} & 23.5651 & 31.8821 & 8.317 \\ 78 & \mathrm{H} & 24.5881 & 31.8821 & 7.294 \\ 80 & \mathrm{H} & 24.603 & 31.8821 & 7.2791 \\ 82 & \mathrm{H} & 23.8577 & 31.8821 & 8.0244 \\ 86 & \mathrm{H} & 23.7735 & 31.8821 & 8.1086 \\ 88 & \mathrm{H} & 24.5446 & 31.8821 & 7.3375 \\ 90 & \mathrm{H} & 24.4752 & 31.8821 & 7.4069 \\ 92 & \mathrm{H} & 23.5281 & 31.8821 & 8.354 \\ 184 & \mathrm{H} & 22.7955 & 31.8821 & 9.0866 \\ 186 & \mathrm{H} & 25.405 & 31.8821 & 6.4771 \\ 188 & \mathrm{H} & 27.6923 & 31.8821 & 4.1898 \\ 190 & \mathrm{H} & 24.6493 & 31.8821 & 7.2328\end{array}$

Triptycene 2

$\begin{array}{lcccc}\text { ID } & \text { Atom type } & \text { Isotropic (ppm) } & \text { TMS Shielding } & \text { Scaled (ppm) } \\ 121 & \mathrm{H} & 23.8517 & 31.8821 & 8.0304 \\ 123 & \mathrm{H} & 24.6006 & 31.8821 & 7.2815 \\ 125 & \mathrm{H} & 24.5923 & 31.8821 & 7.2898 \\ 127 & \mathrm{H} & 23.566 & 31.8821 & 8.3161 \\ 111 & \mathrm{H} & 23.7621 & 31.8821 & 8.12 \\ 113 & \mathrm{H} & 24.5219 & 31.8821 & 7.3602 \\ 115 & \mathrm{H} & 24.4413 & 31.8821 & 7.4408 \\ 117 & \mathrm{H} & 23.5159 & 31.8821 & 8.3662 \\ 102 & \mathrm{H} & 24.662 & 31.8821 & 7.2201 \\ 104 & \mathrm{H} & 27.6864 & 31.8821 & 4.1957 \\ 106 & \mathrm{H} & 25.3965 & 31.8821 & 6.4856 \\ 108 & \mathrm{H} & 22.7871 & 31.8821 & 9.095\end{array}$

\section{Section F. References}

1) Jiang, X.; Duan, H.-B.; Khan, S.I.; Garcia-Garibay, M.A. Diffusion-Controlled Rotation of Triptycene in a Metal-Organic Framework (MOF) Sheds Light on the Viscosity of MOF-Confined Solvent. ACS Central Science, 2016, 2, 608-613

2) Wazeer, M. I. M.; Ali, Sk.A.; Arab, M. Synthesis and carbon-13 NMR study of some methanesulfonyloxy and trifluoroacetoxy derivatives of naphthalene. Spectrochimica Acta, Part A: Molecular and Biomolecular Spectroscopy 1987, 6, 843-847.

3) Salomon-Ferrer, R.; Götz, A. W.; Poole, D.; Le Grand, S.; Walker, R. C. Routine Microsecond Molecular Dynamics Simulations with AMBER on GPUs. 2. Explicit Solvent Particle Mesh Ewald. $J$. Chem. Theory Comput. 2013, 9, 3878-3888.

4) Case, D. A.; Cerutti, D. S.; Cheatham, III, T. E.; Darden, T. A.; Duke, R. E.; Giese, T. J.; Gohlke, H.; Goetz, A. W.; Greene, D.; Homeyer, N.; Izadi, S.; Kovalenko, A.; Lee, T. S.; LeGrand, S.; Li, P.; Lin, C.; Liu, J.; Luchko, T.; Luo, R.; Mermelstein, D.; Merz, K. M.; Monard, G.; Nguyen, H.; Omelyan, I.; Onufriev, A.; Pan, F.; Qi, R.; Roe, D. R.; Roitberg, A.; Sagui, C.; Simmerling, C. L.; Botello-Smith, W. M.; Swails, J.; Walker, R. C.; Wang, J.; Wolf, R. M.; Wu, X.; Xiao, L.; York, D. M.; Kollman, P. A. AMBER 2017, University of California, San Francisco.

5) Wang, J. M.; Wolf, R. M.; Caldwell, J. W.; Kollman, P. A.; Case, D. A. Development and Testing of a General Amber Force Field. J. Comput. Chem. 2004, 25, 1157-1174.

6) Peters, M. B.; Yang, Y.; Wang, B.; Füsti-Molnár, L.; Weaver, M. N.; Merz, K. M. Structural Survey of Zinc-Containing Proteins and Development of the Zinc AMBER Force Field (ZAFF). J. Chem. Theory Comput. 2010, 6, 2935-2947.

7) Li, P.; Merz, K. M. MCPB.py: A Python Based Metal Center Parameter Builder. J. Chem. Inf. Model. 2016, 56, 599-604.

8) Gaussian 09, Revision D.01, Frisch, M. J.; Trucks, G. W.; Schlegel, H. B.; Scuseria, G. E.; Robb, M. A.; Cheeseman, J. R.; Scalmani, G.; Barone, V.; Mennucci, B.; Petersson, G. A.; Nakatsuji, H.; Caricato, M.; Li, X.; Hratchian, H. P.; Izmaylov, A. F.; Bloino, J.; Zheng, G.; Sonnenberg, J. L.; Hada, M.; Ehara, M.; Toyota, K.; Fukuda, R.; Hasegawa, J.; Ishida, M.; Nakajima, T.; Honda, Y.; Kitao, O.; Nakai, H.; Vreven, T.; Montgomery, Jr., J. A.; Peralta, J. E.; Ogliaro, F.; Bearpark, M.; Heyd, J. J.; Brothers, E.; Kudin, K. N.; Staroverov, V. N.; Keith, T.; Kobayashi, R.; Normand, J.; Raghavachari, K.; Rendell, A.; Burant, J. C.; Iyengar, S. S.; Tomasi, J.; Cossi, M.; Rega, N.; Millam, J. M.; Klene, M.; 
Knox, J. E.; Cross, J. B.; Bakken, V.; Adamo, C.; Jaramillo, J.; Gomperts, R.; Stratmann, R. E.; Yazyev, O.; Austin, A. J.; Cammi, R.; Pomelli, C.; Ochterski, J. W.; Martin, R. L.; Morokuma, K.; Zakrzewski, V. G.; Voth, G. A.; Salvador, P.; Dannenberg, J. J.; Dapprich, S.; Daniels, A. D.; Farkas, O.; Foresman, J. B.; Ortiz, J. V.; Cioslowski, J.; Fox, D. J. Gaussian, Inc., Wallingford CT, 2013.

9) Becke, A. D. Density functional Thermochemistry. III. The Role of Exact Exchange. J. Chem. Phys. 1993, 98, 5648-5652.

10) Lee, C.; Yang, W.; Parr, R. G. Development of the Colle-Salvetti Correlation-Energy Formula into a Functional of the Electron Density. Phys. Rev. B 1988, 37, 785-789.

11) Bayly, C. I.; Cieplak, P.; Cornell, W.; Kollman, P. a. A Well-Behaved Electrostatic Potential Based Method Using Charge Restraints for Deriving Atomic Charges: The RESP Model. J. Phys. Chem. 1993, 97, 10269-10280.

12) Hay, P. J.; Wadt, W. R. Ab Initio Effective Core Potentials for Molecular Calculations. Potentials for the Transition Metal Atoms Sc to Hg. J. Chem. Phys. 1985, 82, 270-283.

13) Besler, B. H.; Merz, K. M.; Kollman, P. A. Atomic Charges Derived from Semiempirical Methods. J. Comput. Chem. 1990, 11, 431-439.

14) Singh, U. C.; Kollman, P. A. An Approach to Computing Electrostatic Charges for Molecules. $J$. Comput. Chem. 1984, 5, 129-145.

15) Maier, J. A.; Martinez, C.; Kasavajhala, K.; Wickstrom, L.; Hauser, K. E.; Simmerling, C.

ff14SB: Improving the Accuracy of Protein Side Chain and Backbone Parameters from ff99SB. J. Chem.

Theory Comput. 2015, 11, 3696-3713.

16) Darden, T.; York, D.; Pedersen, L. Particle Mesh Ewald: An $N \cdot \log (\mathrm{N})$ Method for Ewald Sums in Large Systems. J. Chem. Phys. 1993, 98, 10089.

17) Laio, A.; Parrinello, M. Escaping free-energy minima. Proc. Natl. Acad. Sci. U.S.A. 2002, 99, 12562-12566.

18) Barducci, A.; Bonomi, M.; Parrinello, M. Metadynamics. Wiley Interdiscip. Rev. Comput. Mol. 2011, 1, 826-843.

19) Phillips, J. C.; Hardy, D. J.; Maia, J. D. C.; Stone, J. E.; Ribeiro, J. V.; Bernardi, R. C.; Buch, R.; Fiorin, G.; Hénin, J.; Jiang, W.; McGreevy, R.; Melo, M. C. R.; Radak, B. K.; Skeel, R. D.; Singharoy, A.; Wang, Y.; Roux, B.; Aksimentiev, A.; Luthey-Schulten, Z.; Kalé, L. V.; Schulten, K.; Chipot, C.; Tajkhorshid, E. Scalable molecular dynamics on CPU and GPU architectures with NAMD. J. Chem. Phys 2020, 153, 044130-044163.

20) Ilott, A. J.; Palucha, S.; Hodgkinson, P.; Wilson, M. R. Well-Tempered Metadynamics as a Tool for Characterizing Multi- Component, Crystalline Molecular Machines. J. Phys. Chem. B 2013, 117, 12286.

21) Davidchack, R. L.; Handel, R.; Tretyakov, M. V. Langevin thermostat for rigid body dynamics. $J$. Chem. Phys 2009, 130, 234101-234116. 